\title{
Class-Specific Cell Death Shapes the Distribution and Pattern of Central Projection of Cat Retinal Ganglion Cells
}

\author{
Audie G. Leventhal, Jeffrey D. Schall, ${ }^{a}$ Steven J. Ault, Jan M. Provis, ${ }^{b}$ and Dagmar J. Vitek \\ Department of Anatomy, University of Utah School of Medicine, Salt Lake City, Utah 84132
}

The development of the nasotemporal division in cat retina was studied. We find that in the normally pigmented neonatal cat significant numbers of ganglion cells of all types in temporal retina project to the contralateral dorsal lateral geniculate nucleus (LGNd); far fewer cells in temporal retina project contralaterally to the LGNd in the normal adult. Thus, most of these cells must be eliminated during development.

Experimental interruption of one optic tract in the neonate results in the retrograde degeneration of the ipsilaterally projecting ganglion cells in the temporal retina ipsilateral to the lesion. Consequent to the loss of the ipsilaterally projecting cells in this hemiretina, many of the ganglion cells projecting to the intact contralateral LGNd, which are normally eliminated, survive. Also, unlike in the normal cat, in which very few of the small ganglion cells in temporal retina project contralaterally to the thalamus, in optic tract sectioned (OTX) cats, significant numbers of the smallest ganglion cells in the temporal retina ipsilateral to the lesion project contralaterally to the intact thalamus.

In order to make a quantitative comparison of the distributions of ipsilaterally and contralaterally projecting cells in the temporal retinae of normal cats, OTX cats, and neonatal kittens, it was necessary to determine the position of the vertical meridian in all animals. We defined the vertical meridian as the median edge (Stone, 1966). The median edge was determined from the distribution of the most nasally located, ipsilaterally projecting cells in temporal retina. The results indicate that the angle of the vertical meridian (median edge) with respect to the area centralis and optic disc is specified before birth and does not differ in normal cats, OTX cats, or neonatal kittens. Since the location of the vertical meridian does not change with age in postnatal life and is not affected by optic tract section, corresponding regions of retina in the different groups could be compared.

A quantitative analysis of ganglion cell density in the temporal retina contralateral to the section, ipsilateral to the intact hemisphere, indicated that there was a reduction in the population of ipsilaterally projecting ganglion cells that

\footnotetext{
Received May 21, 1987; revised Oct. 14, 1987; accepted Oct. 20, 1987.

This investigation was supported by PHS Grant EY04951 to A.G.L., NRSA EY05863 to S.J.A., and NRSA EY05767 to D.J.V.

Correspondence should be addressed to Audie G. Leventhal at the above address.

a Department of Brain and Cognitive Science, E25-634, MIT, Cambridge, MA 02139.

b Department of Clinical Ophthalmology, Sydney Eye Hospital, Sydney, Australia 2011

Copyright (C) 1988 Society for Neuroscience $0270-6474 / 88 / 062011-17 \$ 02.00 / 0$
}

was complementary to the abnormally large number of contralaterally projecting cells surviving in the temporal retina ipsilateral to the lesion. As a result of this complementary loss, the intact LGNd in OTX cats receives inputs from normal numbers of $\alpha$ and $\beta$ cells at all elevations.

The foregoing results suggest that the axons of retinal ganglion cells of like type in the 2 eyes compete in the LGNd during development. This competition promotes a classspecific cell death that helps shape the development of the retinal distribution and pattern of central projections of the different classes of ganglion cells in the mature cat retina.

During development a complex series of events, still poorly understood, results in an intricate pattern of connectivity between axons and their targets. A number of lines of evidence suggest that an initial overproduction of cells coupled with selective cell death contributes to adult specificity (Oppenheim, 1981; Cowan and O'Leary, 1984; Hamburger and Oppenheim, 1982).

Mammalian retina contains a number of different ganglion cell types having different morphological forms, physiological properties, and central projections (reviewed by Stone et al., 1979). Anatomical tracing studies (Leventhal et al., 1985b) indicate that no 2 visual nuclei receive direct inputs from the samc complement of retinal ganglion cell types. Studies of the development of cat retina indicate that most retinal ganglion cells die during the development of this precise and complex pattern of central projection ( $\mathrm{Ng}$ and Stone, 1982; Stone et al., 1982; Williams et al., 1985). It has been estimated that 800,000 900,000 ganglion cells are produced during the development of cat retina and that about $80 \%$ of these die during development. As many as 100,000 cells are lost during the first few weeks postnatally (Williams et al., 1985). The cat visual pathway thus provides a useful system in which to study cell death and the mechanisms mediating the development of the connectivity of the mammalian CNS.

This report provides evidence that the axons of retinal ganglion cells of like type in corresponding positions of the 2 eyes interact in retinal recipient nuclei during development. These interactions mediate a class-specific, position-dependent death of retinal ganglion cells in the neonate and thereby shape the retinal distribution and distinctive pattern of central projection of the different classes of retinal ganglion cells.

\section{Materials and Methods}

Subjects. Nine homozygous, normally pigmented cats received successful unilateral electrolytic or knife-sections of the optic tract (OTX) on postnatal day $(\mathrm{P})$ one. The OTX kittens were then reared normally 

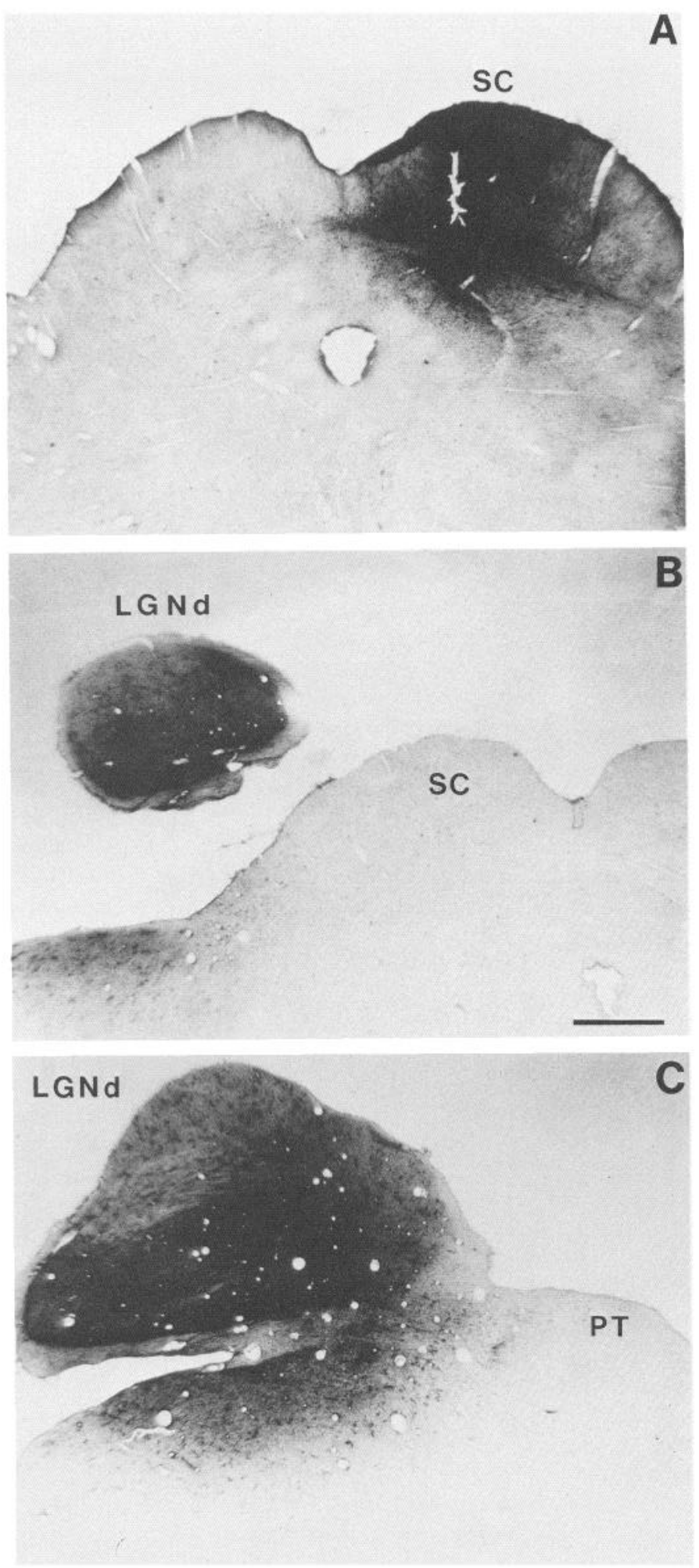

Figure 1. Photomicrographs of HRP injection sites in the superior colliculus of an OTX cat $(A)$ and in the LGNd of a second OTX cat $(B$ and $C$ ). In $A$, the injection site is restricted to the superior colliculus; in $B$ and $C$, HRP reaction product is evident throughout the LGNd but is completely absent from the superior colliculus $(s c)$ and pretectum $(p t)$, respectively. In $B$, the posterior portion of the LGNd, the region representing inferior retina, is shown. Even though HRP reaction product extended into the posterior portion of the LGNd, only a few lightly labeled cells were found more than $3 \mathrm{~mm}$ into inferior retina. Scale bar, $1 \mathrm{~mm}$. in our breeding colony and received electrophoretic HRP injections into the dorsal lateral geniculate nucleus (LGNd) or superior colliculus in adulthood. Prior to injecting HRP, the LGNd and areas 17 and 18 of these cats were studied electrophysiologically. These results are presented in detail in the accompanying paper (Schall et al., 1988). Twelve normal cats provided control data.

Surgery, preparation, HRP injection, histology, histochemistry, and quantitative morphological analyses. These procedures have been described in detail previously (Leventhal, 1982; Leventhal et al., 1985b; 1988).

Distribution of labeled cells. The distributions of all labeled retinal ganglion cells in regions of interest were plotted using the camera lucida. Outside of the area centralis region, the densities of cells of different types in $0.5 \mathrm{~mm}$ square regions of retina were determined. Within the area centralis, the densities of cells of different types within $0.25 \mathrm{~mm}$ square regions were determined.

Determination of the vertical meridian. In the present study, the vertical meridian was taken to be the median edge (Stone, 1966). The median edge was determined in 17 animals (see Results) and was defined as the line passing through the nodal point (area centralis) and the most nasally located ipsilaterally projecting cells (Stone, 1966; Cooper and Pettigrew, 1979a). In the retinae contralateral to the HRP injections, direct localization of the median edge (vertical meridian) was difficult due to the lack of a sharp border (see also Cooper and Pettigrew, 1979a). In these retinae the vertical meridian was taken to be a line passing through the area centralis angled at the value determined for the ipsilateral retina of the same cat. A detailed discussion and definitions of the different retinal meridians were presented by Cooper and Pettigrew (1979a).

\section{Results}

We have analyzed the retinal distribution and central projections of ganglion cells in the retinae of normal adult cats and of adult cats that received optic tract lesions as neonates. Normal 1-d-old kittens were also studied to provide information about the pattern of central projection of retinal ganglion cells in the neonate. Operated animals received HRP injections into the LGNd or superior colliculus contralateral to the optic tract section (Fig. 1). Our results, described below, provide evidence that the retinal distribution and pattern of central projection of the retinal ganglion cells surviving optic tract section are abnormal and are not simply predicted from the death of the cells whose axons were cut by the lesion.

\section{Determination of the vertical meridian (median edge)}

In order to compare corresponding regions in the different groups of animals studied, it was necessary to determine accurately the position of the vertical meridian (median edge) as defined in Materials and Methods. We therefore determined the vertical meridian in all groups of animals. We find that the angle of the vertical meridian is not significantly different in neonatal, OTX, and normal cats. In the superior retina of all animals studied $(N=17)$ the median edge was, on average, angled at $111.3^{\circ}$ $\left(\mathrm{SD}=1.8^{\circ}\right)$ to the line connecting the center of the area centralis with the center of the optic disc. The mean value for normal cats was $111.5^{\circ}\left(\mathrm{SD}=0.8^{\circ}\right)$; neonatal kittens, $112.1^{\circ}\left(\mathrm{SD}=2.3^{\circ}\right)$, and OTX, $110.6^{\circ}\left(\mathrm{SD}=1.9^{\circ}\right)$. These values do not differ significantly and agree well with those obtained by Stone (1966) and Cooper and Pettigrew (1979a). Since the position of the vertical meridian did not differ among the groups, the distributions of ipsilaterally and contralaterally projecting cells in corresponding retinal regions could be compared in different animals. 
The Journal of Neuroscience, June 1988, 8(6) 2013

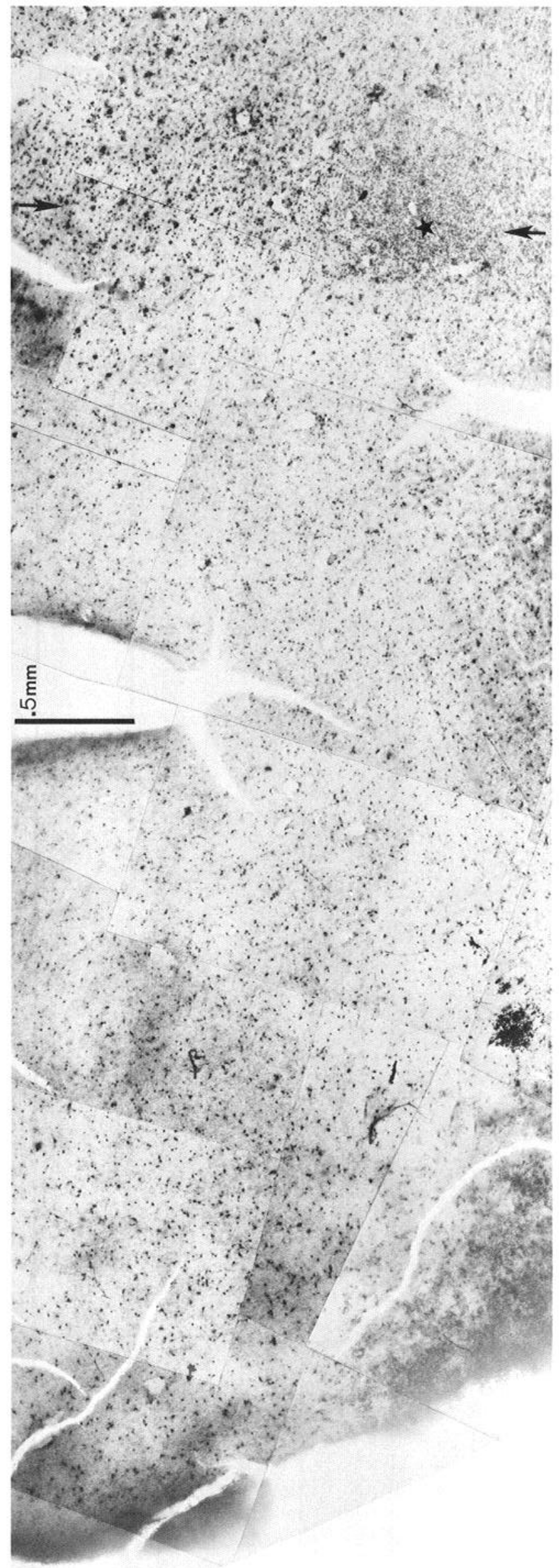




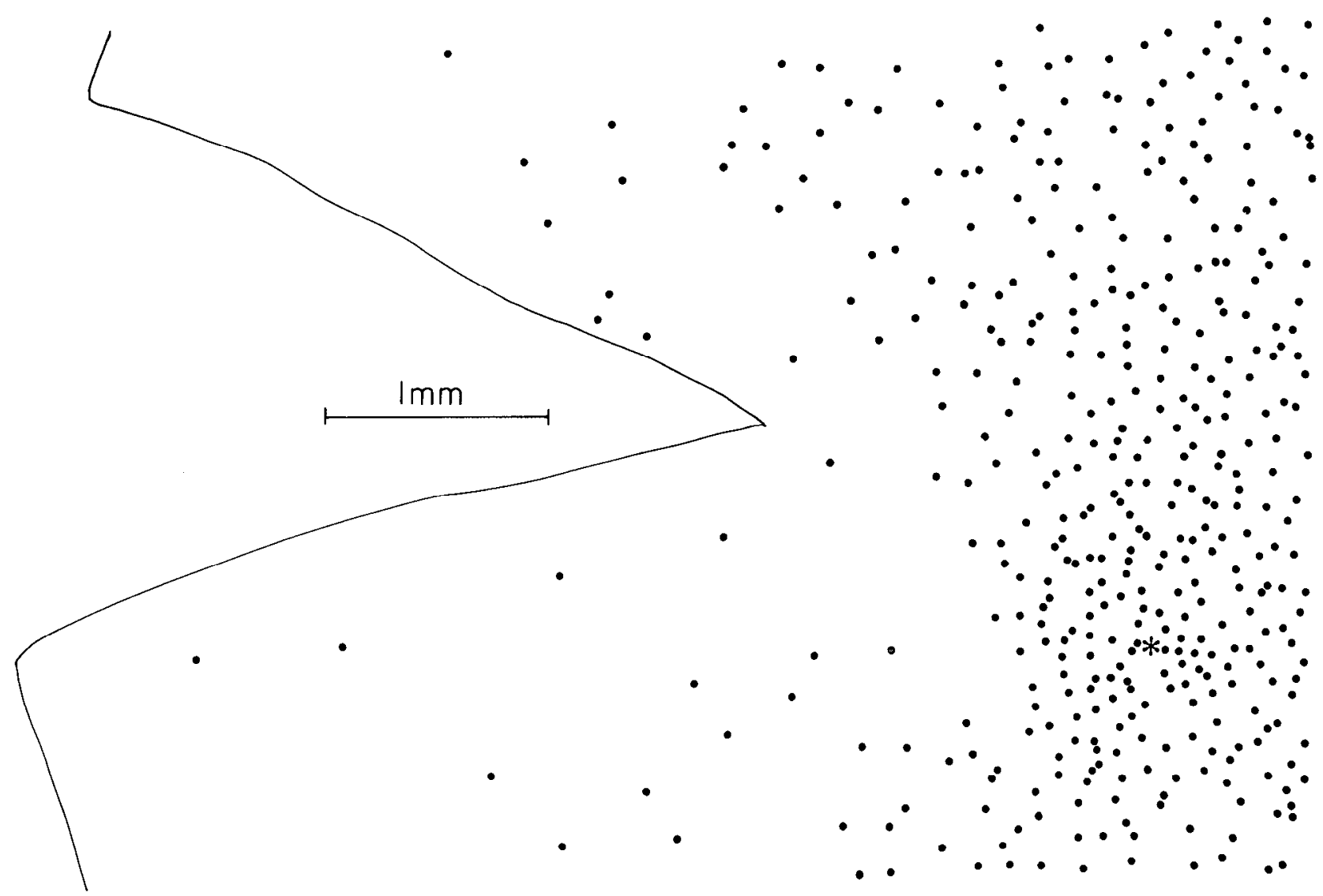

Figure 3. Distribution of contralaterally projecting $\alpha$ cells in the temporal retina of the neonatal kitten. The dots indicate the positions of the cell bodies of $\alpha$ cells labeled by an injection of HRP into the contralateral LGNd. Temporal retina is to the left, and the area centralis is indicated by the asterisk. Note the abundance of contralaterally projecting $\alpha$ cells in temporal retina. In the neonatal kitten retina $1 \mathrm{~mm}$ subtends about $7^{\circ}$ of visual angle compared with about $4.4^{\circ}$ in the adult cat.

\section{Nasotemporal division in the neonate}

In the normal adult cat, very few cells in temporal retinae project contralaterally to the thalamus; virtually all cells projecting contralaterally to the thalamus in regions more than a few hundred micrometers into temporal retina are $\alpha$ cells (Cooper and Pettigrew, 1979a; Illing and Wässle, 1981; see Figs. 5-8).

To date, the distributions of ipsilaterally and contralaterally projecting ganglion cells in the neonatal cat retina have not been reported. We therefore injected HRP into one LGNd of 1-dold kittens. The results of these experiments showed that neonatal kittens have many more contralaterally projecting cells in temporal retina than do normal adult animals (Figs. 2, 3, and also 8). Moreover, unlike in the adult cat, ganglion cells representing all somal size classes were labeled in contralateral temporal retina of the neonate following our injections into the LGNd (see Fig. 12).

Figure 2 shows a photomicrograph of the temporal retina contralateral to an LGNd injection in the neonate. The animal was injected on P1 and perfused on P3. An abundance of cells were labeled throughout the temporal retina. Figure 3 shows the temporal retina contralateral to an LGNd injection in a second kitten injected on P1. The positions of all labeled $\alpha$ cells in regions close to the horizontal meridian are indicated. Note that many contralaterally projecting $\alpha$ cells extend far into temporal retina. In the neonate, $1 \mathrm{~mm}$ of retina subtends about $7^{\circ}$ of visual angle compared with about $4.4^{\circ}$ in the adult. Thus, in this animal contralaterally projecting $\alpha$ cells effectively covered $25^{\circ}$ of the retina.

\section{Temporal retina ipsilateral to the optic tract section}

We compared the number and distribution of cells in temporal retina labeled by injections of HRP into the contralateral LGNd in normal cats with the number and distribution of cells in temporal retina labeled by injections of HRP into the contralateral LGN in OTX cats. As a control, we determined the overall distribution of contralaterally projecting cells in the temporal retina of normal adult cats by making multiple HRP injections into the optic tract $4-5 \mathrm{~mm}$ from the optic chiasm (Figs. $5,6)$. As a result of HRP into the intact LGNd in OTX cats (contralateral to the optic tract section), many labeled cells were evident in the temporal retina ipsilateral to the optic tract section (Fig. 4). These contralaterally projecting cells were far more numerous and extended further into temporal retina than contralaterally projecting cells in the temporal retinae of normal 

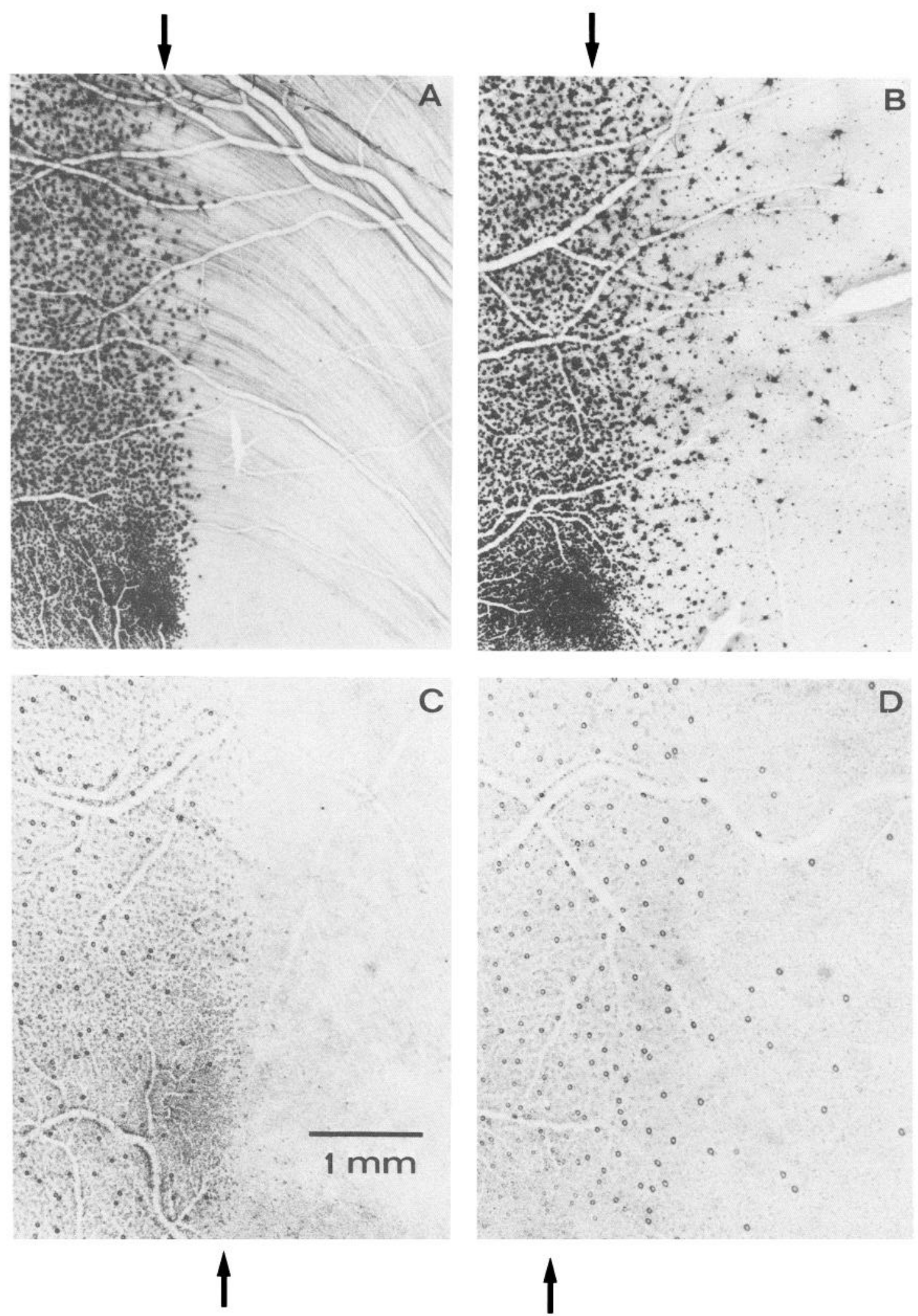

Figure 4. Distribution of ganglion cells in adult cat retina following neonatal, unilateral optic tract lesion. $A$ and $B$, Photomicrographs of HRPlabeled ganglion cells in both retinae of an adult cat whose left optic tract was sectioned on P1. The arrows indicate the nasotemporal division with nasal retina toward the center. The retina shown in $A$ was contralateral to the lesioned hemisphere, ipsilateral to the intact hemisphere into which HRP was injected. The retina shown in $B$ was ipsilateral to the lesion, contralateral to the injection. $C$ and $D$, Photomicrographs of Nissl-stained ganglion cells. The retinae are displayed as in $A$ and $B$. The vertical meridian (median edge) is clearly visible in $A$ and $C$. 
Figure 5. Photomicrographs of contralaterally projecting ganglion cells in temporal retina of 2 normal cats ( $A$ and $B)$ and an OTX cat $(C)$. The cells in $A$ were labeled by multiple injections of HRP in the optic tract. The cells in $B$ and $C$ were labeled by injections of HRP into the LGNd. The vertical meridian is indicated by the arrows; scale bar, 1 $\mathrm{mm}$. The regions shown in $A$ and $C$ are along the horizontal meridian; the region in $B$ is $5 \mathrm{~mm}$ above the horizontal meridian. Note that, in the normal cat, virtually all contralaterally projecting ganglion cells in temporal retina are small in regions more than a few hundred micrometers from the vertical meridian $(A)$. Occasionally, a few contralaterally projecting $\alpha$ cells as far as 2 $\mathrm{mm}$ into temporal retina are labeled at peripheral elevations (see also Fig. $7 A$ ) as a result of injections of HRP into the normal LGNd $(B)$. In contrast, many contralaterally projecting cells of all types $(C)$ are labeled in temporal retina, even along the horizontal meridian, as a result of injections into the LGNd of OTX cats. Scale bar, $0.5 \mathrm{~mm}$.

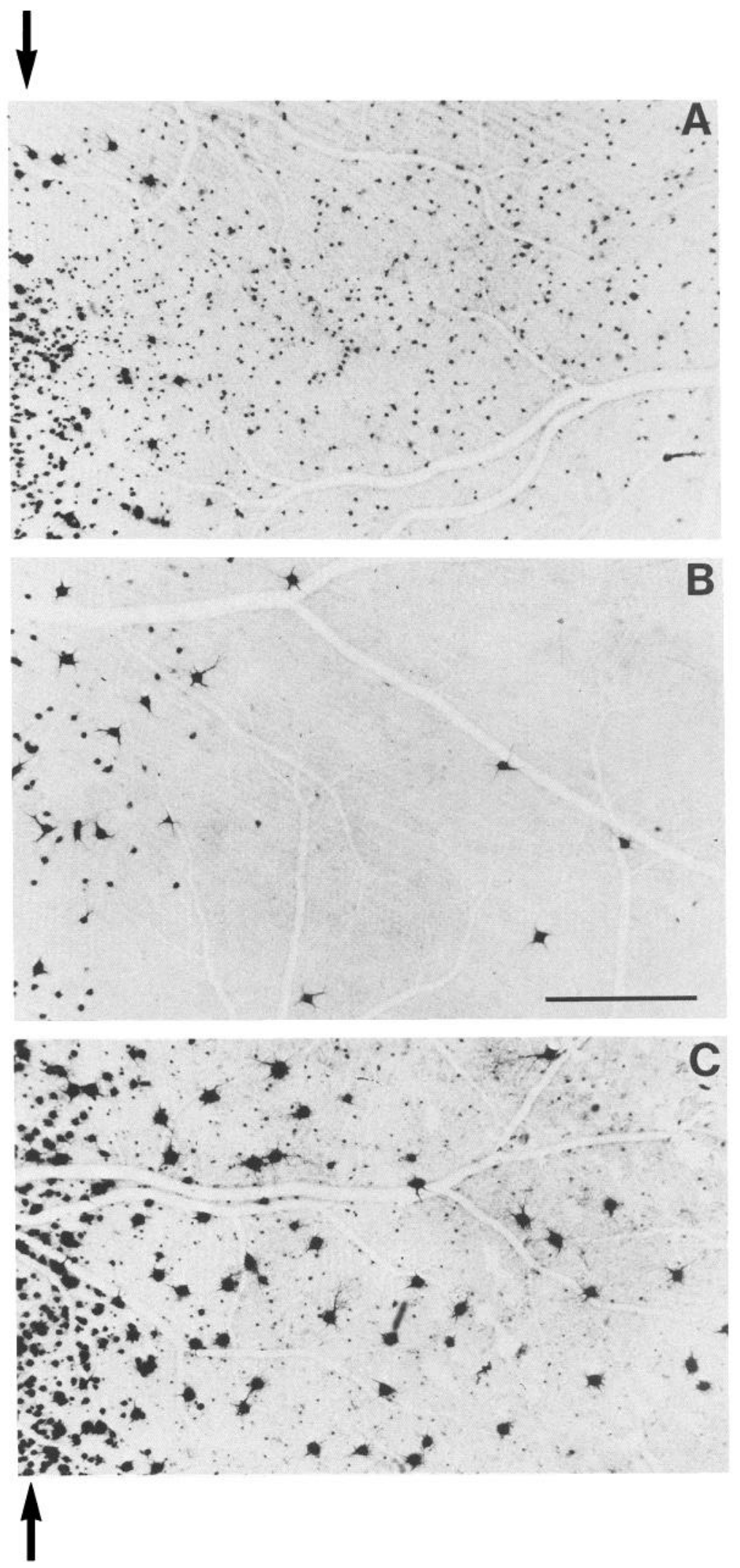



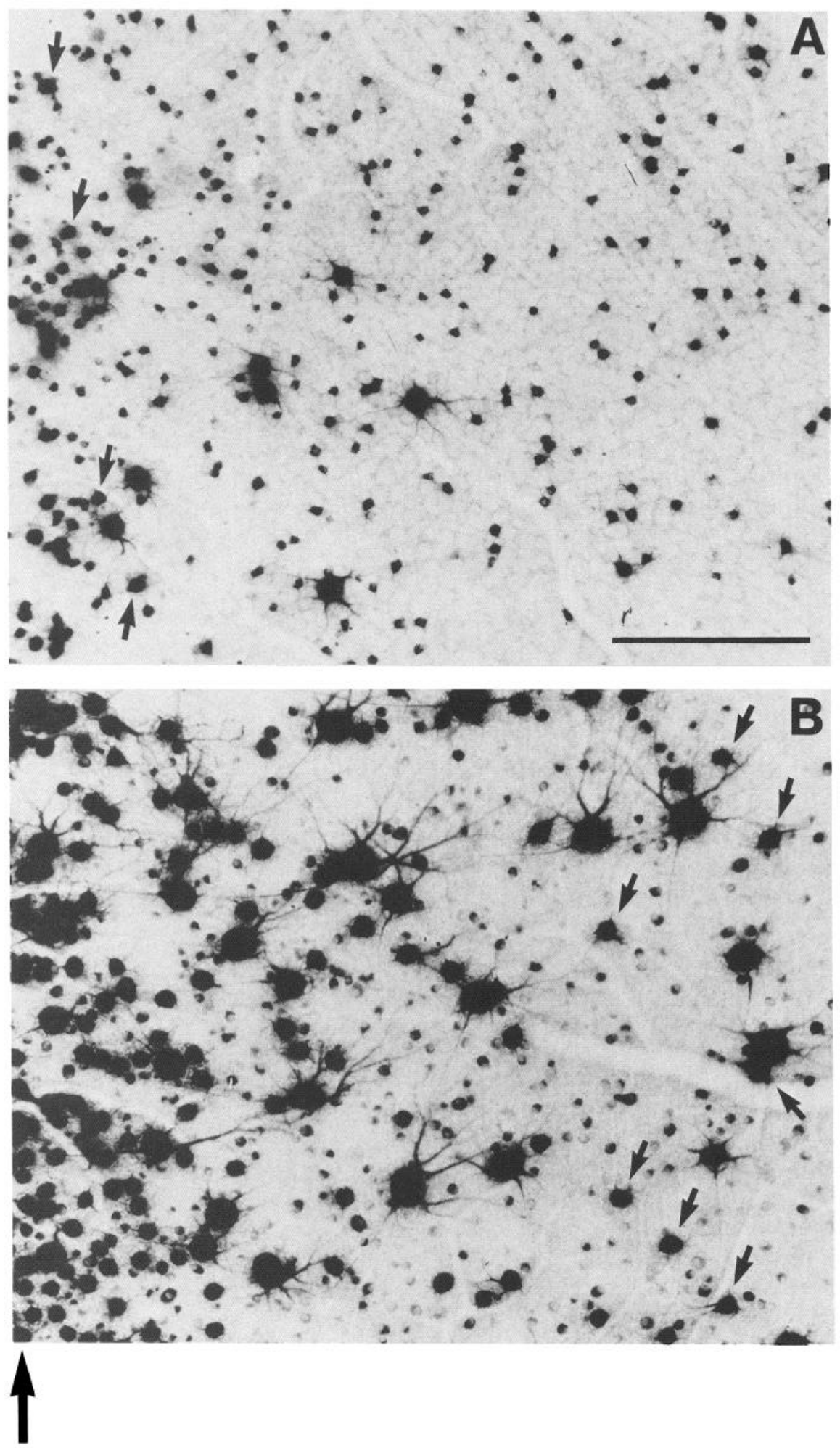

Figure 6. Higher-power photomicrograph of contralaterally projecting cells in temporal retina of a normal cat $(A)$ following multiple optic tract injections and an OTX cat $(B)$ following LGNd injections. The regions shown are along the horizontal meridian. The vertical meridian is indicated by the arrows. Notice that at elevations close to the horizontal meridian, in the temporal retina of the normal cat, virtually all contralaterally projecting cells more than a few hundred micrometers from the vertical meridian are small. In OTX cats, small cells as well as many large $\alpha$ and $\beta$ cells (arrows) along the horizontal meridian in temporal retina project contralaterally to the LGNd. Scale bar, $250 \mu \mathrm{m}$. 

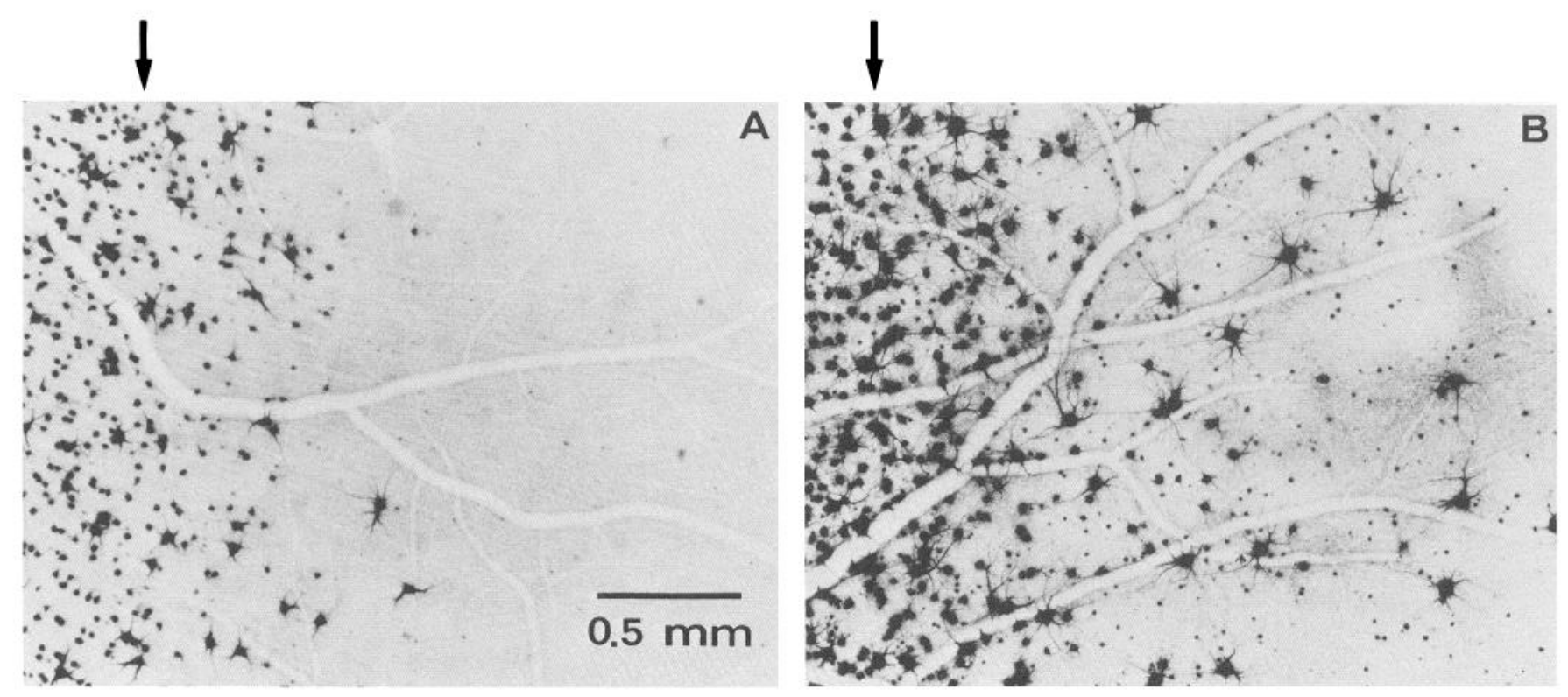

Figure 7. Distribution of contralaterally projecting ganglion cells in temporal retina of a normal cat $(A)$ and a neonatally optic tract sectioned cat $(B)$. The arrows indicate the vertical meridian. Temporal retina is to the right. Both regions are $1-2$ mm above the horizontal meridian. Note that the density of contralaterally projecting ganglion cells in the OTX cat is greater than normal. At this elevation in normal cats contralaterally projecting cells do not extend more than $1 \mathrm{~mm}$ or so into temporal retina (see also Fig. $5 B$ ).

adult cats (Figs. 5-8). ${ }^{1}$ Overall, contralaterally projecting cells in the temporal retina of OTX cats were less numerous than were contralaterally projecting cells in the temporal retina of the neonatal kittens studied (Fig. 8).

In most of the retinae examined, the cell bodies and dendritic fields of the labeled cells were stained well enough to determine their morphological type. Along the horizontal meridian (Figs. 5,6 ) in the temporal retina ipsilateral to the lesion, numerous contralaterally projecting $\beta$ cells were found as far as $1.5 \mathrm{~mm}$ from the vertical meridian; some contralaterally projecting $\beta$ cells were found as far as $3 \mathrm{~mm}$ into temporal retina. Along the horizontal meridian, numerous contralaterally projecting $\alpha$ cells extended over $2.5 \mathrm{~mm}$ from the vertical meridian. Even following large optic tract injections in normal cats significant numbers of contralaterally projecting $\alpha$ and $\beta$ cells do not extend more than a few hundred micrometers into temporal retina along the horizontal meridian (Figs. 5, 6, and also 13).

\footnotetext{
' There is some evidence in the literature (Cooper and Pettigrew, 1979a, Fig. 4) that, at peripheral elevations in normal cats, a small number of $\alpha$ cells in superior temporal retina project contralaterally in regions as far as $2-2.5 \mathrm{~mm}$ from the vertical meridian. We have also occasionally seen such cells in normal cats at peripheral elevations (Fig. $5 B$ ). In these cases, the number of contralaterally projecting $\alpha$ cells is still far fewer than the number we have observed in OTX cats and neonatal kittens at all elevations. Also, recent evidence (Leventhal et al., 1985 a) indicates that "normally" pigmented cats that carry the recessive allele for albinism have an abnormally large number of contralaterally projecting $\alpha$ and $\beta$ cells in temporal retina. These animals also exhibit an abnormal representation of the ipsilateral hemifield in visual cortex. Siamese cats are a form of albino; the recessive allele for the Siamese abnormality is very common in the "normal" cat population. Given the existence of heterozygote effects, comparisons between the present results and those obtained previously must be made cautiously.

All animals included in the present study were raised in our well-established breeding colony; all cats in the colony are homozygous and normally pigmented. The normally pigmented adult cats we have studied from our colony do not have significant numbers of contralaterally projecting $\alpha$ and $\beta$ cells more than 1 and $0.4 \mathrm{~mm}$, respectively, into temporal retina at an elevation close to the horizontal meridian. In agreement with Cooper and Pettigrew (1979a) and Illing and Wässle (1981), we do not find significant numbers of small or medium-sized cells labeled in the contralateral temporal retina in regions more than few hundred micrometers from the vertical meridian following injections into the thalamus of normal cats (Fig. 5B).
}

At elevations 1-2 $\mathrm{mm}$ above the horizontal meridian, many contralaterally projecting $\alpha$ and $\beta$ cells extended as far as 4 and $2 \mathrm{~mm}$, respectively, from the vertical meridian (Figs. 7, 8). At all elevations in OTX cats some contralaterally projecting $\alpha$ cells were found throughout temporal retina; many contralaterally projecting ganglion cells of other types $(\epsilon, \mathrm{g} 1, \mathrm{~g} 2$ cells: Leventhal, 1982; Leventhal et al., 1985b) extended throughout temporal retina (Figs. 5, 6, and also 12). ${ }^{2}$ Following large injections of HRP into the LGNd of normal cats, far fewer cells in temporal retina project contralaterally, even at more peripheral elevations (Fig. 6), where the region of nasotemporal overlap is normally widest (Illing and Wässle, 1981).

At all other elevations studied, contralaterally projecting cells in OTX cats were more numerous and extended further into temporal retina than normal. However, as in normal cats (Illing and Wässle, 1981), in OTX cats contralaterally projecting cells extended progressively further into temporal retina in regions progressively further from the horizontal meridian (Figs. 5, 6).

It is important to point out that, while overall there were fewer contralaterally projecting cells in the temporal retina of the OTX cat than in the temporal retina of the neonate, similar numbers of contralaterally projecting $\alpha$ cells were found in both groups (Figs. 3, 8). Thus, neonatal optic tract section results in the stabilization of the entire exuberant $\alpha$ cell projection but only part of the exuberant projection from other cell types.

\footnotetext{
${ }^{2}$ Cell types other than $\alpha$ and $\beta$ project to the LGNd (Illing and Wässle, 1981; Rowe and Dreher, 1982; Leventhal, 1982; Leventhal et al., 1985b) from the ipsilateral temporal retina. These cells project to the LGNd C laminae, MIN, and geniculate wing (Leventhal et al., 1980, 1985b; Rowe and Dreher, 1982). These cells are mostly medium-sized and have been termed $\epsilon$ cells (Leventhal et al., 1980 ) and g1 cells (Leventhal, 1982; Leventhal et al., 1985b). G1 cells are differentiated from g2 cells since g2 cells are smaller and project in large numbers to the superior colliculus, pretectum, and ventral lateral geniculate nucleus, but very few project to the LGNd (Leventhal et al., 1985b). By definition, g2 cells are the smallest ganglion cells in cat retina (Leventhal, 1982; Leventhal et al., 1985b) and are a heterogenous subset (the smallest cells) in the group Wässle and Illing (1980) and Illing and Wässle (1981) refer to as $\gamma$ cells. These authors apparently refer to all cells, other than $\beta$ cells, with small and medium-sized cell bodies as $\gamma$ cells.
} 


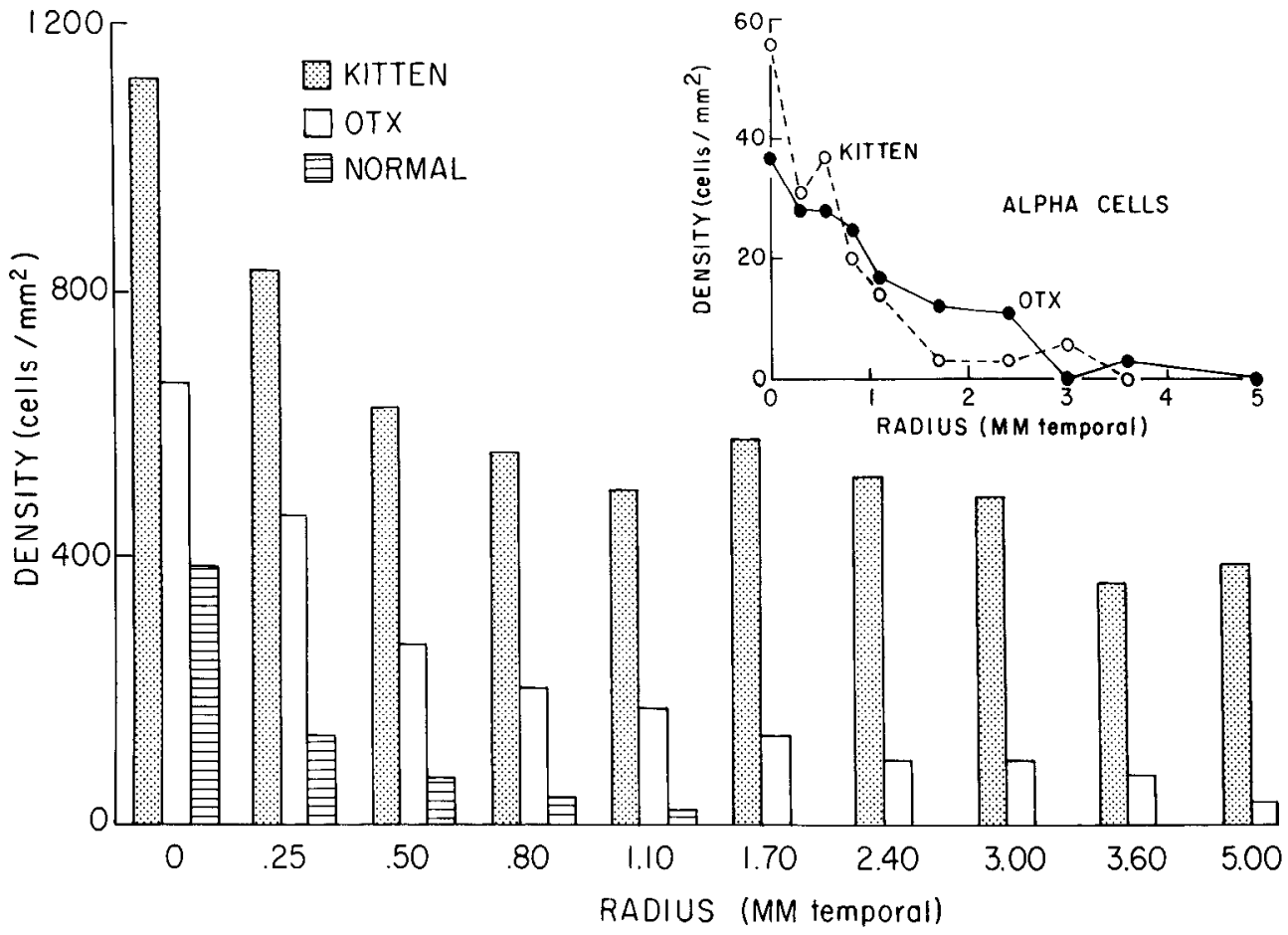

Figure 8. Density of contralaterally projecting cells in the temporal retina of neonatal cats, OTX cats, and normal cats. The abscissa indicates the distance from the vertical meridian at an elevation just above the horizontal meridian. Note that there are many more contralaterally projecting cells in the temporal retina of the neonatal kitten than in the adult. An intermediate number of contralaterally projecting cells are found in the OTX cat. Also note that the density of contralaterally projecting $\alpha$ cells (inset) in temporal retina of the OTX cat and the neonate are similar. Thus, neonatal optic tract section stabilizes the entire exuberant $\alpha$ cell projection but less than half of the exuberant projection from the remaining cell types. In this and other figures, distances in kitten retina have been adjusted for growth hased upon the results of Mastronarde et al. (1984).
In the OTX cats, the surviving contralaterally projecting $\alpha$ and $\beta$ cells in temporal retina are abnormally large. This is presumably because they were located in regions of reduced ganglion cell density. A complete analysis of changes in retinal ganglion cell morphology associated with a reduction in the density of neighboring cells is presented in the accompanying paper (Leventhal et al., 1988).

\section{Temporal retina contralateral to the optic tract section}

We compared the number and distribution of cells in temporal retina labeled by HRP injections into the ipsilateral LGNd in normal cats with the number and distribution of cells in temporal retina labeled by injections into the ipsilateral (surviving) LGNd in OTX cats. The results provide evidence that the number and distribution of labeled cells in the temporal retina ipsilateral to the injection (contralateral to the lesion) in OTX cats was abnormal. In all cats studied, fewer than the normal number of cells in temporal retina projected ipsilaterally to the intact LGNd (Figs. 9-12). Along the horizontal meridian a "loss" of ipsilaterally projecting $\alpha$ cells was evident up to $2.5 \mathrm{~mm}$ from the vertical meridian (Figs. 9-11); a "loss" of $\beta$ cells was evident up to $1.5 \mathrm{~mm}$ from the vertical meridian (Fig. 11). In regions away from the horizontal meridian, the number of ipsilaterally projecting $\alpha$ and $\beta$ cells was reduced 4 and $2 \mathrm{~mm}$, respectively, into temporal retina. When the distribution of $\alpha$ and $\beta$ cells in the 2 temporal retinae were compared, we found that, at all elevations studied (superior retina and the horizontal meridian), the reduction in the number of ipsilaterally projecting cells in the temporal retina ipsilateral to the intact hemisphere (Figs. 9-11) complemented the abnormally large contralateral projection to the intact hemisphere from the temporal retina ipsilateral to the lesion (the "depleted" temporal retina).

It is noteworthy that the surviving, ipsilaterally projecting $\alpha$ and $\beta$ cells close to the vertical meridian in the temporal retina ipsilateral to the intact LGNd of OTX cats were abnormally large. Increases in cell body and dendritic field sizes are con- sequences of a reduction in ganglion cell density (Leventhal et al., 1988) and provide evidence that the density of cells was actually reduced in the regions studied.

The loss of cells we observed cannot be accounted for by incomplete HRP staining since the same results were evident in Nissl-stained retinae (Fig. 10); all HRP-stained retinae examined were counterstained with thionin, and the regions analyzed quantitatively contained no unlabeled $\alpha$ and $\beta$ cells. It should also be stressed that this cannot be a result of the lesion itself since the lesion would only have killed those cells in the "undepleted" temporal retina that projected to the contralateral hemisphere in the neonate; we have specifically compared the numbers of cells projecting ipsilaterally in normal and OTX cats (Figs. 9-11). Moreover, since our procedures stain the axons and dendrites of virtually all cells in areas of interest, the possibility that the "lost" $\alpha$ and $\beta$ cells are present but shrunken can be ruled out.

\section{The Nasal Retina}

Following injections of HRP into the intact LGNd contralateral to the optic tract section, a small number of cells were labeled in the nasal retina ipsilateral to the injection (the depleted nasal retina). Almost all of thcsc cells were $\mathrm{g} 2$ cells (Leventhal, 1982; Leventhal et al., 1985b). Occasionally gl and $\epsilon$ cells were labeled. Very occasionally an $\alpha$ or a $\beta$ cell was labeled.

Jacobs et al. (1984) injected HRP into the optic tracts of kittens and OTX cats and reported that more cells in the nasal retina project ipsilaterally in the kitten (about 600 cells) than in the adult (about 75 cells); neonatal optic tract section results in about a 2-fold increase in the number of ipsilaterally projecting cells in nasal retina of the adult. It is worth noting that our injections of HRP into the LGNd never labeled as many ipsilaterally projecting cells as Jacobs et al. (1984) labeled by injecting the optic tract. Following LGNd injections in kittens and normal and OTX cats, we observed, on average, about 40 ipsilaterally projecting cells in nasal retina; one of our OTX cats 

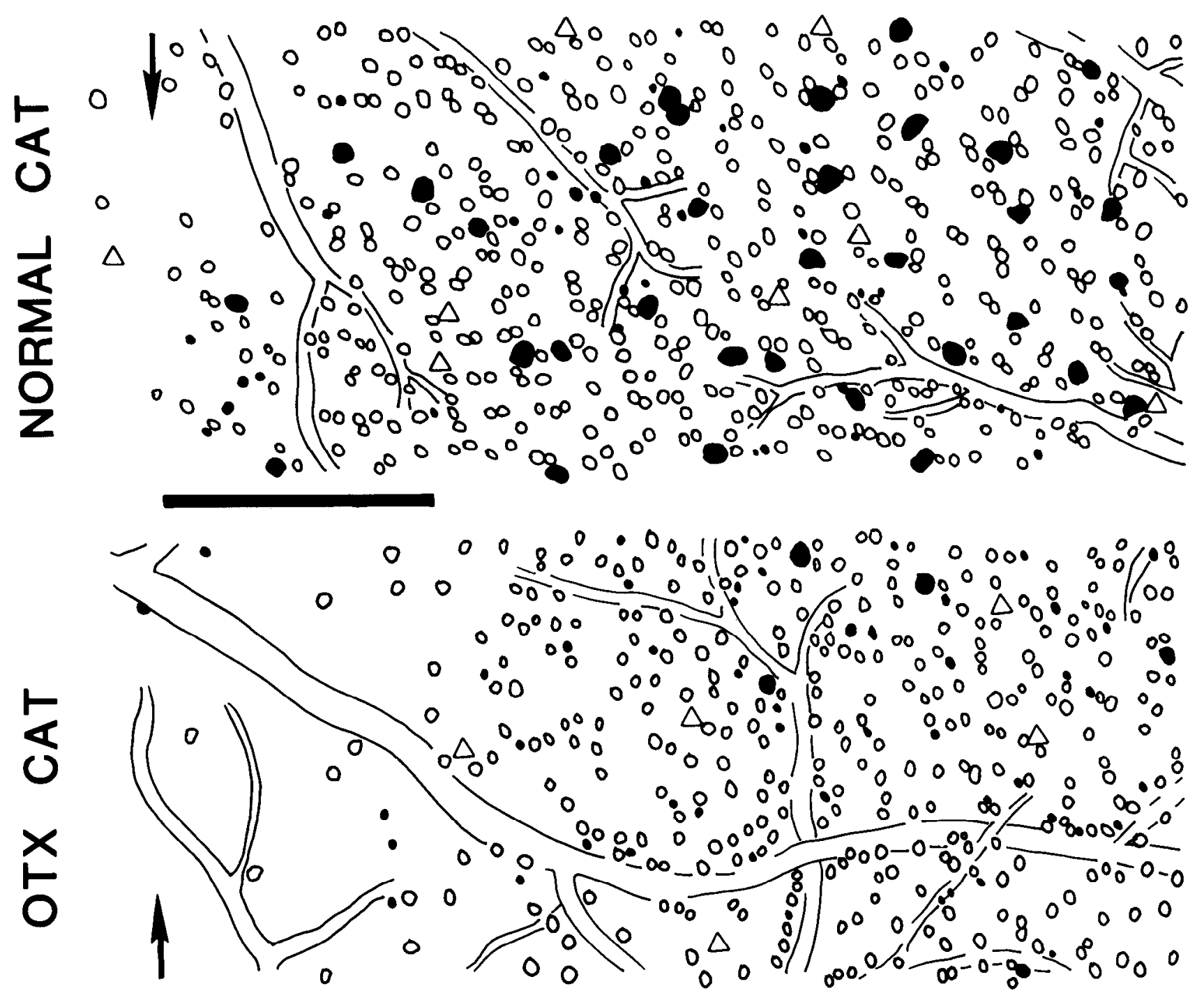

Figure 9. Distribution of ipsilaterally projecting ganglion cells in temporal retina of normal (upper) and neonatally OTX cat (lower). The $\alpha$ cells are represented by large solid spots; $\beta$ cells are represented by open spots; $\epsilon$ cells are represented by triangles, and other cell types are represented by small solid spots. The samples are from corresponding regions of retina, $1 \mathrm{~mm}$ dorsal to the horizontal meridian, and are aligned so that the vertical meridian (arrows) is on the left. Scale bar, $1 \mathrm{~mm}$. Note the reduction in ganglion cell density in the temporal retina ipsilateral to the intact LGNd in the OTX cat. It is evident from this figure that the $\beta$ cells close to the vertical meridian in OTX cats are larger than their normal countcrparts. This is a conscquence of the reduction in ganglion cell density in the region (Leventhal et al., 1988).

had less than 20 cells labeled in the ipsilateral nasal retina. Thus, it would seem that most of the ipsilaterally projecting cells in nasal retina do not project to the LGNd but to some other retinorecipient region such as the superior colliculus (Wässle and Illing, 1980).

As a result of HRP injections into the intact LGNd (contralateral to the optic tract section), the number and distribution of cells labeled in the contralateral nasal retina were found to be within the normal range. This is not surprising since, as noted above, an extremely small number of cells in nasal retina project ipsilaterally, even in the kitten (Jacobs et al., 1984); optic tract section would only be expected to cut the axons of a few cells in the ipsilateral nasal retina. It is not possible to detect such a small change (about $0.1 \%$ ) using our procedures.

\section{Projection to the superior colliculus}

As a result of injections into the superior colliculus of the OTX cat (Fig. 1), $\alpha$ cells, many g2 cells, and a few $\mathrm{g} 1$ and $\epsilon$ cells were labeled (Fig. 13). We did not observe any labeled $\beta$ cells as a result of our injections. ${ }^{3}$ Since large numbers of cells of types other than $\alpha$ and $\beta$ in temporal retina normally project contralaterally to the superior colliculus (Wässle and Illing, 1980), it is difficult to say whether the projection from the contralateral temporal retina to the superior colliculus is abnormal in OTX cats. To answer this question requires a quantitative analysis in animals in which the injection site includes the retinorecipient layers of the superior colliculus in their entirety but avoids the

\footnotetext{
${ }^{3}$ Wässle and Illing (1980) made large injections of HRP into the superior colliculus. They observed a small number of labeled $\beta$ cells as a result of their injections. Leventhal et al. (1985b) made smaller injections into the superior colliculus and did not observe any labeled $\beta$ cells. Small injections into the pretectum (Leventhal et al., 1985b) did result in labeled $\beta$ cells. Thus, at present, it is not clear whether (1) injections of HRP into the superior colliculus label $\beta$ cells only if the pretectum is included in the effective injection site or (2) large injections, but not small injections, into the superior colliculus label $\beta$ cells whether or not the pretectum is involved.
} 
Percent of Normal
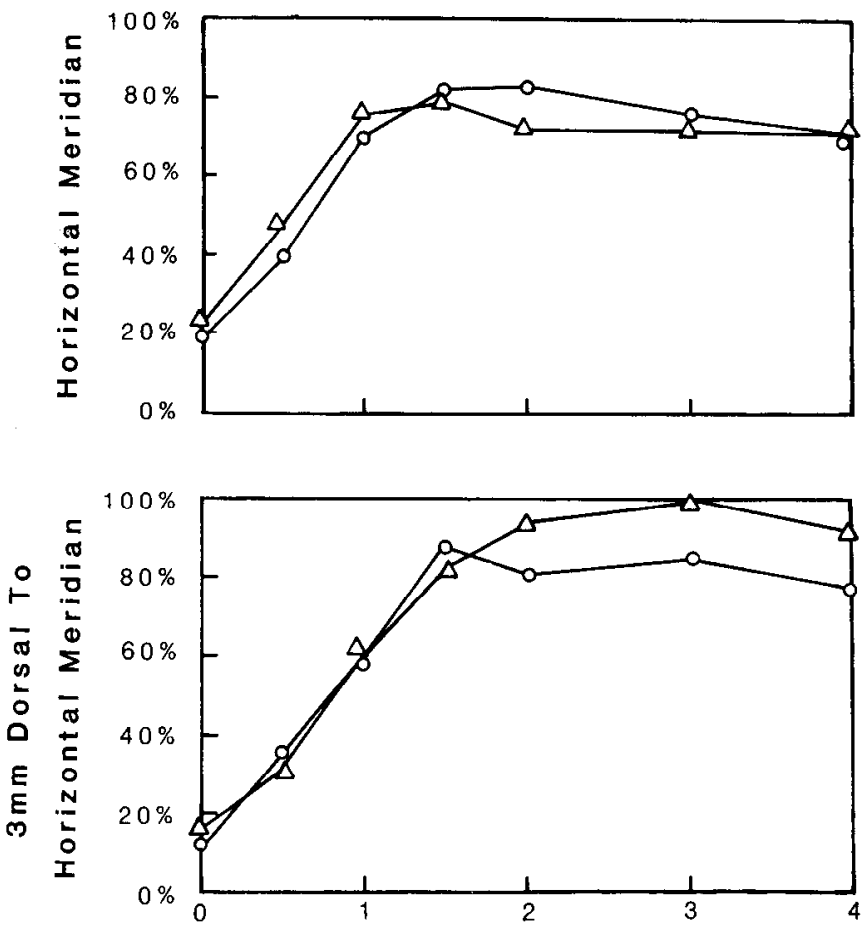

Azimuth $(\mathrm{mm})$

Figure 10. Reduction in density of ipsilaterally projecting $\alpha$-type ganglion cells in 2 OTX cats. The retinae of these 2 cats were stained with thionin. A decrease in density of $\alpha$ cells is evident both on the horizontal meridian and $3 \mathrm{~mm}$ dorsal to the horizontal meridian. While $\beta$ cells cannot be differentiated in the Nissl (thionin)-stained material, a reduction in the number of medium-sized cells close to the vertical meridian was evident in both Nissl-stained retinae.

pretectum, optic tract, and LGNd. It does not seem possible to make such an injection.

\section{Discussion}

The findings of this study are summarized in Figure 14. Many cells in temporal retina project contralaterally to the LGNd in the neonatal, normally pigmented kitten. Cells of all sizes, and presumably all classes, comprise this contralateral temporal projection. During the first weeks of normal development, most of these cells die. Thus, in the normal adult, far fewer cells in temporal retina project contralaterally to the LGNd (Cooper and Pettigrew, 1979a; Illing and Wässle, 1981).

If one optic tract is sectioned in the neonate, many of the contralaterally projecting ganglion cells in temporal retina survive in the eye ipsilateral to the section. Cells belonging to all somal size classes comprise this "stabilized exuberant" projection. The survival of $\alpha$ and $\beta$ cells in the temporal retina ipsilateral to the tract section is accompanied by a complementary loss of ipsilaterally projecting $\alpha$ and $\beta$ cells in the temporal retina contralateral to the tract section. This loss of cells is likely to be due to some sort of central axonal interaction; the optic tract section could not have directly resulted in the loss of ipsilaterally projecting cells in the contralateral eye.

\section{Technical considerations}

In order to properly interpret the results presented, 2 potential problems must be discussed. The first is whether an error in
LOSS OF ALPHA AND BETA GANGLION CELLS

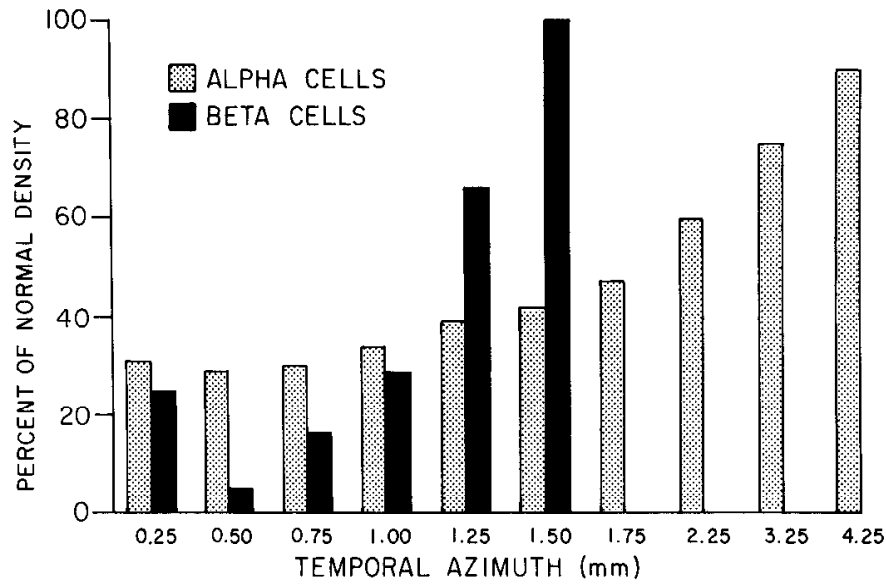

Figure 11. Bar graph illustrating the loss of ipsilaterally projecting $\alpha$ and $\beta$ cells in the temporal retina contralateral to the optic tract section. Results for all animals are combined. Results are for regions $2-3 \mathrm{~mm}$ dorsal to the horizontal meridian. Note the dramatic decrease in the number of $\alpha$ and $\beta$ cells in temporal retina.

localizing the position of the vertical meridian in the different groups of animals studied could have affected our results. The sccond is whether our obscrvations could have been affected by an involvement of the superior colliculus and/or optic tract in the effective uptake sites resulting from an HRP injection into the LGNd.

The first issue to deal with is the reliability of the localization of the vertical meridian in different animals. As presented in Materials and Methods, we defined the vertical meridian in all cats as the median edge (Stone, 1966). We found that in the superior retinae of kittens, OTX cats, and normal cats, the median edge defined on average, an angle of $111.3^{\circ}$ with the line connecting the center of the area centralis with the center of the optic disc (see also Cooper and Pettigrew, 1979a). In normal cats and kittens, ${ }^{4}$ the same value accurately defined the border separating regions containing labeled and unlabeled cells in the retina ipsilateral to the injection; in OTX cats, this angle defined the border separating regions containing ganglion cells from those which did not (Fig. 4) in the retina contralateral to the section (ipsilateral to the injection). Since the median edge was defined by the same angle in all groups of animals, comparisons between equivalent points on the retinae of normal, OTX cats, and kittens could be made with confidence.

The results we report are also unlikely to be affected by an error in the localization of the vertical meridian for a number of other reasons. First, in HRP- and Nissl-stained material, $\alpha$ cell numbers in OTX cats are reduced at most elevations at least $4 \mathrm{~mm}$ into the temporal retina ipsilateral to the injection

\footnotetext{
${ }^{4}$ In the ferret the angle of the median edge relative to the area centralis and optic disc is similar to the angle in cat (Vitek et al., 1985). Ferrets are born at a much earlier stage of development than the cat. We have recently begun to study the development of the nasotemporal division in newborn ferrets. Our results indicate that the position of the median edge (nasotemporal division) is specified at birth (E42) in the ferret. This suggests that the position of the vertical meridian in the cat should be specified over 3 weeks before birth (E65). Also, in the ferret as in the cat, (1) the number of ipsilaterally projecting cells in nasal retina and contralaterally projecting cells in temporal retina decrease during the first few weeks of life, and (2) at all ages, the number of contralaterally projecting cells in temporal retina is greater than the number of ipsilaterally projecting cells in nasal retina (i.e., the nasotemporal division is "sharper" in the eye ipsilateral to the HRP injection).
} 


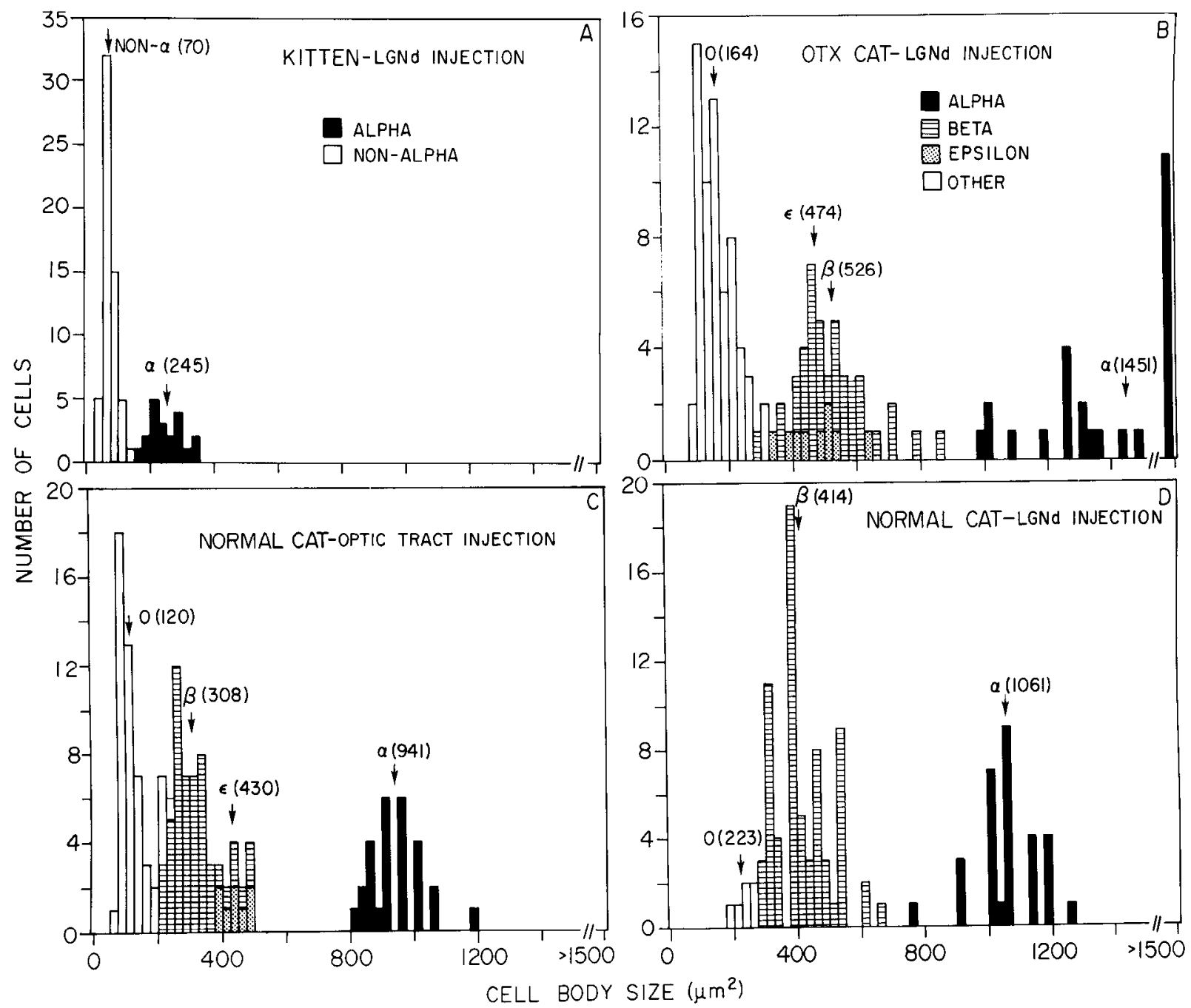

Figure 12. Cell body sizes of cells in the contralateral temporal retina of the neonatal kitten $(A)$ and OTX cat $(B)$ labeled by HRP injections into the LGNd. All injections were centered in the $A$ laminae. The distribution of sizes of cells in the ipsilateral temporal retina labeled by multiple HRP injections into the optic tract of a normal cat $(C)$ is included to show the overall distribution of cell body sizes of ganglion cells in temporal retina. The sizes of cells in the ipsilateral temporal retina labeled by an injection into the LGNd of a normal adult cat is shown in $D$. All histograms were taken from regions of retina about $2 \mathrm{~mm}$ below the horizontal meridian and $2-4 \mathrm{~mm}$ temporal to the vertical meridian (the mean cell body sizes of the different groups are indicated in parentheses). Many cells in the kitten were not stained well enough to classify. We therefore only divided kitten cells into 2 groups in $A$. One group consisted of presumed $\alpha$ cells and the other group consisted of all remaining (non-alpha) cells. In $B-D, O T H E R$ refers to all types of cells other than $\alpha, \beta$, and $\epsilon$ (see Leventhal et al., 1985b). Normally, $\alpha$ and $\beta$ cells and a small number of cells of other types having small to medium-sized cell bodies comprise the input from temporal retina to the ipsilateral LGNd. Very few cells in temporal retina project contralaterally to the LGNd, and very few of the smallest ganglion cells project ipsilaterally to the LGNd. Unlike in the normal cat, in the kitten and OTX cat, cells of all types in temporal retina project contralaterally to the thalamus.

(Fig. 11). Many contralaterally projecting $\alpha$ cells are found up to $4 \mathrm{~mm}$ into the other temporal retina. A $4 \mathrm{~mm}$ error in the localization of the vertical meridian is not possible.

Second, in the retina ipsilateral to the HRP injection, shifting the vertical meridian even $0.5 \mathrm{~mm}$ nasally (Fig. 4) would result in a strip of temporal retina free of ipsilaterally projecting cells in normal cats, kittens, and OTX cats, while shifting the vertical meridian temporally would, by definition, result in large numbers of ipsilaterally projecting cells in nasal retina in normal cats, kittens, and OTX cats. Such an error would be quite obvious; thus, an error in localizing the vertical meridian of more than $100 \mu \mathrm{m}$ is very unlikely in any cat.

The second issue to be dealt with is whether our injections into the LGNd involved the superior colliculus and/or optic tract in OTX or neonatal cats and if this in some way affected our results. For a number of reasons we believe that problems with the injection could not have affected our results significantly.

1. In the normal cat, significant numbers of contralaterally projecting $\alpha$ and $\beta$ cells at elevations close to the horizontal meridian do not extend more than 1 and $0.4 \mathrm{~mm}$ into temporal retina, respectively (Figs. 5-7; see also Stone et al., 1978; Cooper and Pettigrew, 1979a; Wässle and Illing, 1980). Significant numbers of the smallest ganglion cells in temporal retina do project contralaterally (Stone, 1966); these project to the superior colliculus (Wässle and Illing, 1980). In the present study, we made large injections of HRP into the optic tract of normal cats and also found that, at elevations close to the horizontal meridian, virtually all labeled cells more than $1 \mathrm{~mm}$ into the temporal retina contralateral to the injection are small (Figs. 5, 6, 13). We also find that, as in normal cats (Leventhal et al., 1985b), injections of HRP into the superior colliculus of OTX cats label 
mostly g2 cells and $\alpha$ cells and do not label any $\beta$ cells (Fig. 13). In contrast, many $\alpha$ and $\beta$ cells more than $1 \mathrm{~mm}$ into temporal retina at all elevations project contralaterally in the OTX cat; many cells that resemble $\alpha$ and $\beta$ cells at all elevations in temporal retina in the neonate project contralaterally (Figs. 2, 3, 8, 12). Thus, for these cell types, an exuberant projection must exist. Leakage of HRP into the superior colliculus or even the optic tract could not account for our results since injections directly into these structures do not label significant numbers of contralaterally projecting $\alpha$ and $\beta$ cclls in regions of temporal retina more than $1 \mathrm{~mm}$ from the vertical meridian (see also Wässle and Illing, 1980).

2. Reconstructions of our injection sites (Fig. 1) show that HRP reaction product does not extend into the pretectum or superior colliculus in animals receiving LGNd injections. Consistent with this, our injections were made into anterior regions of the LGNd, where the horizontal meridian and superior retina are represented; labeled cells in kittens as well as OTX cats were concentrated in the appropriate regions of retina. Very few cells more than a few millimeters inferior to the horizontal meridian were labeled. No cells in this region were heavily labeled even though some HRP reaction product was evident in the posterior portion of the LGNd (Fig. 1), where the inferior retina is represented. Since the superior colliculus is located posterior to the LGNd, the retinal distribution of labeled cells we observed indicates that the superior colliculus could not have been involved significantly. Similarly, if the optic tract were involved significantly, one would expect a diffuse distribution of labeled cells throughout the retina. The relative absence and poor staining of labeled cells in inferior retina in kittens as well as OTX cats provides evidence that involvement of the optic tract is not a significant problem (see also Cooper and Pettigrew, 1979a, and Illing and Wässle, 1981, regarding the injection of the HRP into the thalamus).

3 . In our experience, good filling of retinal ganglion cell dendrites only is accomplished by long, slow injections in localized regions. Diffuse spread of HRP only results in light labeling of cell bodies. In the present study, the regions analyzed were in retinotopic correspondence with the receptive fields of units recorded at the injection sites and contained well-labeled cells.

In summary, it remains possible that in the present study our determination of the position of the vertical meridian could be wrong by $100 \mu \mathrm{m}$ or so in any individual animal. However, the magnitude and consistent nature of our results cannot be accounted for by small shifts in the position of the vertical meridian. Similarly, our results for $\alpha$ and $\beta$ cells cannot be accounted for by involvement of the midbrain or optic tract in our LGNd injections. Nevertheless, we hesitate to rule out the possibility of a small involvement of these structures in the effective injection sites in neonates. In this study, our injections had to be larger than those in previous studies (Leventhal, 1982; Leventhal et al., 1985b) in order to label large regions of retina in individual cats. Also, HRP injection sites tend to be poor indicators of the effective region of uptake (see Illing and Wässle, 1981 for discussion). In view of the small size of the kitten brain, it remains possible that involvement of the midbrain and optic tract could have contributed to, but for the reasons above, not entirely accounted for, the especially large number of contralaterally projecting small ganglion cells in temporal retina we observed following injections into the LGNd (Fig. 8). Injections into the superior colliculus and/or optic tract do normally label these cells in the adult (Figs. 5, 6; Wässle and Illing, 1980).

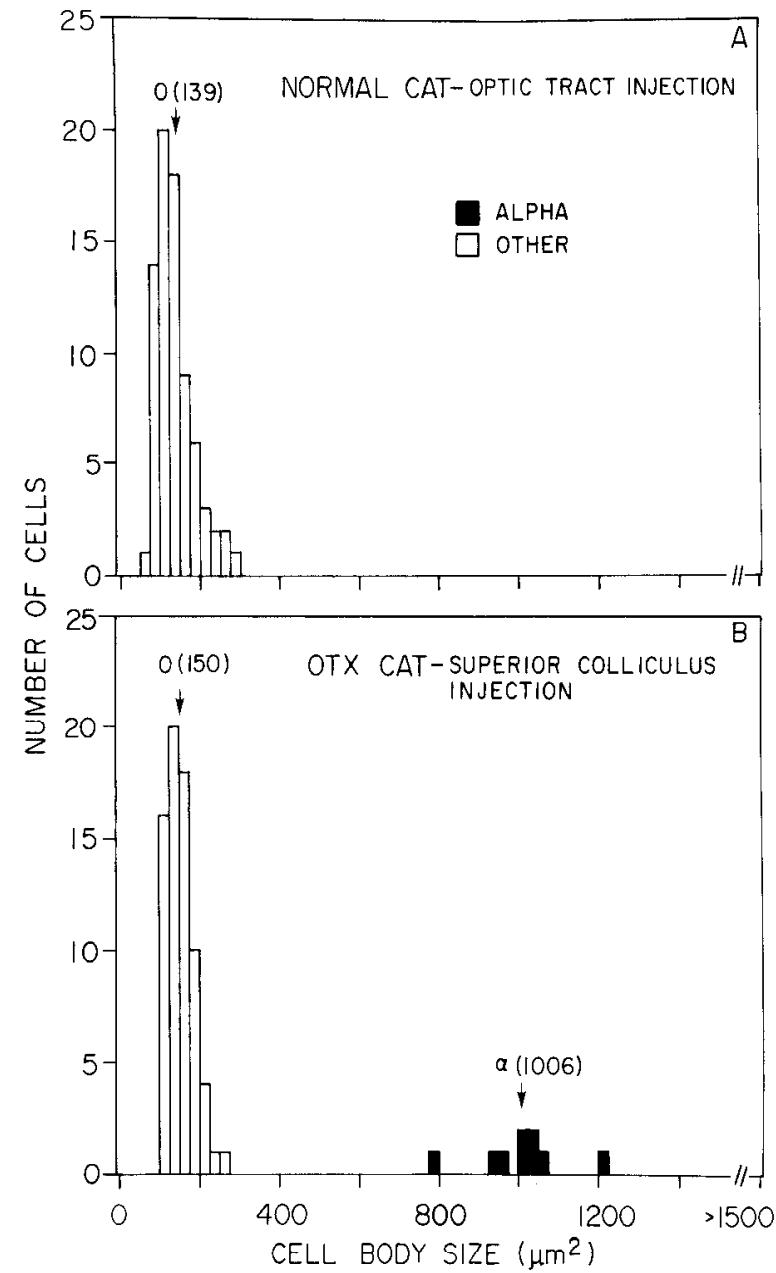

Figure 13. A, Cell body size distribution of contralaterally projecting cells in temporal retina labeled by multiple HRP injections into the optic tract of a normal cat. $B$, Sizes of cells in temporal retina labeled by an injection of HRP into the superior colliculus of an OTX cat. The regions studied were $1-3 \mathrm{~mm}$ from the vertical meridian along the horizontal meridian. In the normal cat, note that there are no contralaterally projecting $\alpha$ and $\beta$ cells $(A)$ more than $1 \mathrm{~mm}$ into temporal retina at elevations close to the horizontal meridian. Also note that our injection into the superior colliculus of the OTX cat did not label any $\beta$ cells (see footnote 3 ).

\section{Evidence that class specific axonal interactions mediate cell death in the developing retina}

In OTX cats, contralaterally projecting $\alpha$ cells are found further into temporal retina than are contralaterally projecting $\beta$ cells. Similarly, in the other eye, a reduction in the number of ipsilaterally projecting $\alpha$ cells is evident further into temporal retina than is a reduction in the number of ipsilaterally projecting $\beta$ cells. We postulate that competitive axonal interactions in the LGNd mediate the effects we observed. A detailed description of the changes in the morphology of retinogeniculate axons that, at least in part, may result from interactions between the axons of retinal ganglion cells in the 2 eyes has recently appeared (Sretavan and Shatz, 1986). Such interactions are the most plausible way to explain why the abnormal survival of cells in one eye projecting to the LGNd is accompanied by a loss of cells in the other eye projecting to the same LGNd. We also hypothesize that the axonal interactions that mediate the loss of ipsilaterally projecting cells are class specific. If they were not, then the 
Figure 14. Summary of results. The distribution of ganglion cells projecting to the 2 hemispheres is represented graphically for the neonate (top), normal adult (lower left), and adult following neonatal optic tract section (lower right). Vertical lines indicate the retinal distribution of ganglion cells projecting ipsilaterally, and horizontal lines indicate the distribution of ganglion cells projecting contralaterally. In the kitten, many cells in temporal retina project contralaterally. Through the course of normal development, most of these cells are eliminated. Sectioning one optic tract neonatally, however, results in the survival of many of the contralaterally projecting cells in the temporal retina ipsilateral to the lesion and a subsequent reduction in the density of ipsilaterally projecting ganglion cells in the temporal retina contralateral to the lesion (indicated by the dashed lines). This reduction in $\alpha$ and $\beta$ cell density is spatially complementary to the increase in ganglion cell density in the other retina.
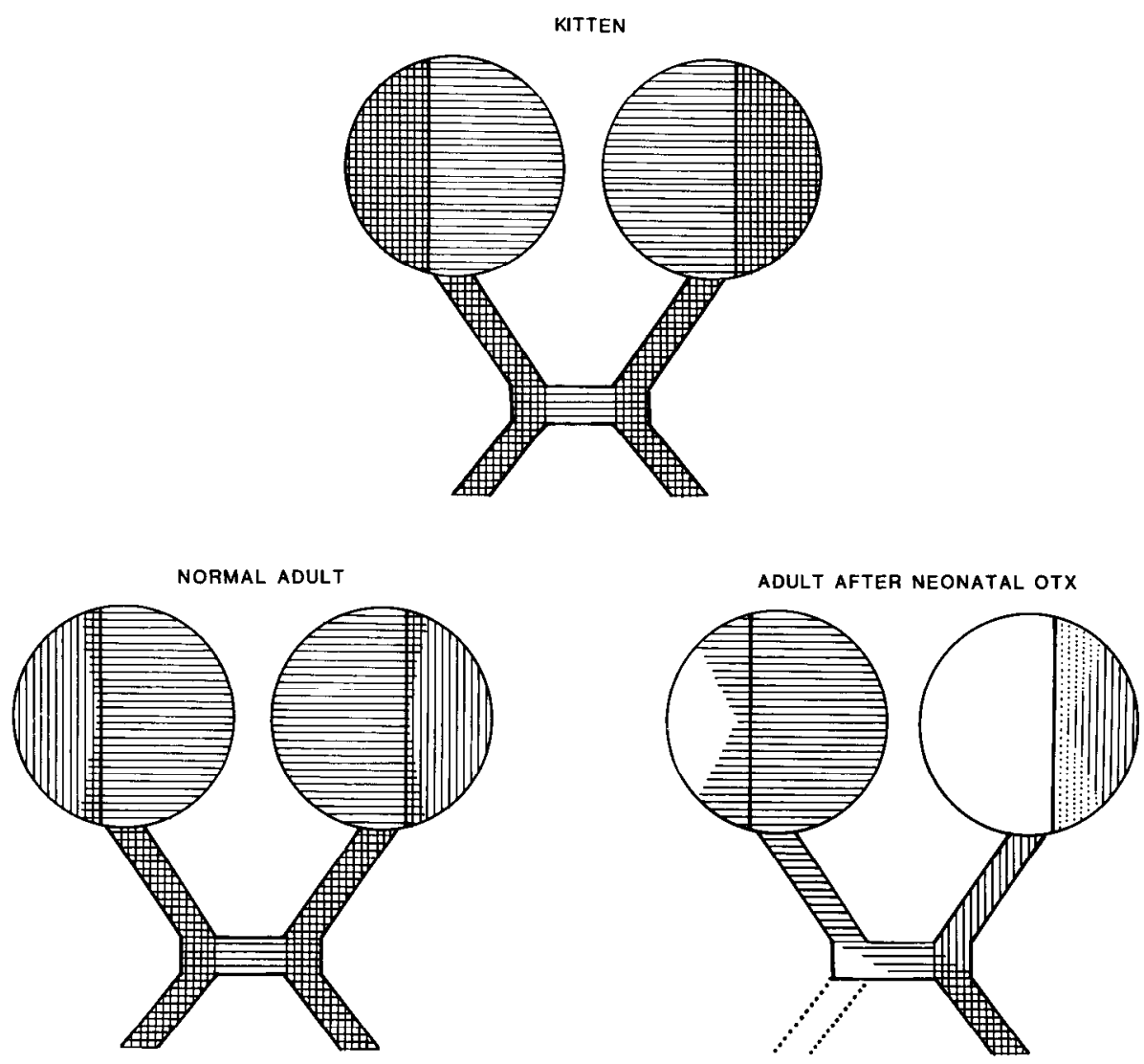

observed loss of cells should reflect the overall distribution of the cells comprising the stabilized exuberant projection. Since the losses of $\alpha$ and $\beta$ cells in one eye were observed to complement the individual distributions of the surviving $\alpha$ and $\beta$ cells in the other eye, some sort of "class specificity" must be involved.

It is not surprising that the cells comprising the exuberant contralateral projection successfully compete with their counterparts in the other eye. It is reported elsewhere (Leventhal et al., 1988) that the surviving contralaterally projecting cells in temporal retina are abnormally largc. This is probably because of reduced intraretinal competition (Linden and Perry, 1982; Perry and Linden, 1982) since the optic tract section caused degeneration of all of the ipsilaterally projecting neighbors of the contralaterally projecting cells. We postulate that the cells comprising the exuberant contralateral temporal projection to the surviving LGNd are at a distinct competitive advantage in OTX cats because of their abnormally large size and the lack of competition for afferent inputs. They, therefore, survive. The reason that these cells die during development in normal animals still requires clarification, but then so do the factors underlying cell death in general.

Normally, relatively few of the smallest ganglion cells in temporal retina project to the LGNd (Kelly and Gilbert, 1975; Cooper and Pettigrew, 1979a; Illing and Wässle, 1981; Leventhal, 1982; Leventhal et al., 1985b). Many of these cells normally project ipsilaterally as well as contralaterally to the midbrain (Kelly and Gilbert, 1975; Wässle and Illing, 1980; Leventhal et al., 1985b). We have found that an abnormally large number of the smallest ganglion cells in temporal retina project contralaterally to the LGNd in neonatal kittens as well as in adult cats receiving optic tract lesions as neonates.
In view of this, we hypothesize that at least part of the cell death occurring postnatally in cat retina represents a second sort of class-related cell death. Specifically, it appears that during the normal development of cat retina, cell types that project to "inappropriate" retinorecipient nuclei are eliminated. This raises the possibility that, in addition to the "within class competition" hypothesized above, competition across retinal ganglion cell classes also occurs during development (see also Sur et al., 1984). Competition among the different ganglion cell classes could help to explain why each retinorecipient nucleus receives inputs from a distinctive complement of ganglion cell types (Leventhal et al., 1985b).

\section{Limitations upon the afferents to the LGNd}

Our finding that the stabilization of the exuberant projection to the LGNd from ganglion cells in one retina results in a complementary loss of cells in the other eye projecting to the same LGNd suggests that the LGNd is normally able to accommodate the axonal arborizations of a limited number of cells. Our results provide no evidence that it is possible to increase the number of ganglion cells projecting to the LGNd postnatally. Evidence that retinorecipient nuclei have a limited ability to receive afferent inputs has also been reported in rodents (reviewed in Schneider et al., 1985) as well as in nonmammalian species (Murray et al., 1982).

\section{Development of the nasotemporal division in normal and hypopigmented cats}

In Siamese (hypopigmented) cats the reduction in the number of ipsilaterally projecting cells seems largely to be due to a pronounced misrouting of axons at the optic chiasm early in development (Kliot and Shatz, 1985). This initial misrouting does 
not explain why in Siamese cats, each LGNd receives inputs from the normal number of $\alpha$ and $\beta$ cells and the distribution of ipsilaterally (normally) projecting $\alpha$ and $\beta$ cells in one temporal retina is always precisely complemented by the distribution of contralaterally (abnormally) projecting $\alpha$ and $\beta$ cells, respectively, in the other temporal retina (Leventhal, 1982). Competition between the axons of retinal ganglion cells of like type in the temporal retinae of the 2 eyes combined with a limitation upon the total retinal input to the LGNd would help to explain the findings in Siamese cats.

A class-specific competitive mechanism of the type described above could also facilitate the development of the patterns of decussation of the different ganglion cell types in normal animals. In particular, it has been shown previously (Stone, 1966; Kirk et al., 1976a, b; Stone et al., 1978; Cooper and Pettigrew, $1979 \mathrm{a}, \mathrm{b}$; Leventhal, 1982) that the different classes of retinal ganglion cells exhibit different patterns of decussation in normal cats. It would seem that class-specific competitive interactions could be a means of achieving this and help to explain why, for example, the distribution of $\alpha$ and $\beta$ cells in the 2 temporal retinae are complementary in normal animals and why a higher proportion of $\alpha$ than $\beta$ cells close to the vertical meridian in temporal retina normally project contralaterally.

\section{Difference between nasal and temporal retina}

In the normal cat, retinal ganglion cell density is lower in temporal than in nasal retina (Stone et al., 1978), and $\alpha$ and $\beta$ cells in temporal retina are larger than their counterparts in nasal retina (Stone et al., 1980). It has been suggested previously (Leventhal, 1982) that the size differences evident among ganglion cells in nasal and temporal retina are, at least in part, due to the lower density of cells in temporal retina. Other factors, however, may also be involved (see Perry et al., 1984, for discussion).

The present results suggest a mechanism by which cell density is selectively reduced in temporal retina. It may be that the elimination of the exuberant projection from contralaterally projecting cells in temporal retina during development contributes to the differences in ganglion cell density in the 2 hemiretinae; this density difference results in cell size differences. Some support for this idea comes from the observations that the magnitude of the difference in cell size between nasal and temporal retina increases about 3-fold in the first weeks of life (see fig. 5 of Rapaport and Stone, 1983); the present results indicate that the number of contralaterally projecting cells in temporal retina is normally reduced during this period.

\section{Width of the region of nasotemporal overlap}

In the normal cat, we have found, in agrcement with Illing and Wässle (1981) that the width of the region of nasotemporal overlap increases with distance from the area centralis. Contralaterally projecting cells are found progressively further into temporal retina at elevations progressively further from the horizontal meridian. Illing and Wässle (1981) pointed out that the width of the region of overlap is inversely related to the density of cells at different elevations and that the same number of cells at all elevations are included in the region of overlap. In OTX cats contralaterally projecting cells are also found progressively further into temporal retina at elevations progressively further from the horizontal meridian; at corresponding elevations contralaterally projecting cells extend further into temporal retina in OTX than in normal cats. Since neonatal optic tract section reduces ganglion cell density at all elevations along the vertical meridian, the present findings can be interpreted as providing further evidence that the density of cells along the vertical meridian somehow contributes to the development of the nasotemporal division; the nasotemporal division is "sharpest" in regions where the density of cells is greatest. The observation that the nasotemporal division is sharper in the monkey than in the cat (Stone et al., 1973) also supports this idea since ganglion cell density is much greater in the former than in the latter (Stone and Johnston, 1981).

This study has provided evidence that the position of the median edge is specified before birth. ${ }^{4}$ Since, in the cat, central retina grows less than peripheral retina in postnatal life (Mastronarde et al., 1984), the relatively large region of overlap in the periphery may result from the early specification of the "nasotemporal" division combined with differential growth in central and peripheral regions of cat retina (see also Illing and Wässle, 1981).

\section{Relation to cell death in other systems}

Throughout the vertebrate nervous system there is a period of naturally occurring cell death during development. Recent work has provided evidence that this cell death promotes the development of mature connectivity in at least 3 ways. The first has been referred to as "systems matching" (reviewed in Oppenheim, 1981; Hamburger and Oppenheim, 1982; Cowan and O'Leary, 1984; Cowan et al., 1984). This term has been used to describe the process by which a target receives the appropriate number of inputs from its afferent neurons. The second can be referred to as "error correction." This term is used here to describe the process by which afferents to inappropriate targets, i.e., aberrant connections, are eliminated (Clarke and Cowan, 1976; Frost and Schneider, 1979; Land and Lund, 1979; McLoon and Lund, 1982; O'Leary and Cowan, 1982; Bunt et al., 1983; O'Leary et al., 1983; Frost, 1984; Godement et al., 1984; Thanos and Bonhoeffer, 1984; Insausti et al., 1985). The third way in which cell death has been shown to aid in the development of mature connectivity is by facilitating "topographic precision." This refers to an apparently activity-dependent process through which cells that project to inappropriate positions within the appropriate target are eliminated (discussion in O'Leary et al., 1986).

The present study provides evidence that the period of naturally occurring cell death which occurs in cat retina $(\mathrm{Ng}$ and Stone, 1982; Stone et al., 1982; Williams et al., 1985) may serve to shape the patterns of projection of the different retinal ganglion cell classes in each of the 3 above-mentioned ways.

First, our findings indicate that an "aberrant" projection from the smallest ganglion cell classes to the LGNd is eliminated during the first wccks of life. This sccms to bc a form of "crror correction" as described above. Second, we found that the stabilized projection from the contralateral temporal retina to the intact LGNd is accompanied by a complementary reduction of ipsilaterally projecting cells. As a result, the surviving LGNd receives normal numbers of inputs in OTX cats. This suggests that cell death during retinal development serves to limit the number of afferent inputs to the LGNd. This can be viewed as a form of "systems matching." Finally, our observation that the topographic distribution of "surviving" cells in the contralateral temporal retina is complementary to the topographic distribution of "lost" cells in the other eye suggests that cell death could potentially serve to refine the topographic precision of the retinogeniculate projection. Substantial evidence that the retraction of much of the neonatal ipsilateral retinocollicular projec- 
tion during development is due to the selective death of ganglion cells has also been presented (Jeffrey and Perry, 1982; O'Leary et al., 1983; Insausti ct al., 1985).

The present findings also suggest a fourth means by which cell death promotes the development of adult specificity. As already discussed, our findings suggest that the interactions that result in the death of ganglion cells in the temporal retina ipsilateral to the intact LGNd are class specific. Class-specific cell death in the mammalian visual system may serve to promote the development of parallel channels in the visual pathways, i.e., the well-documented connections between cells of like type in the retina, LGNd, and visual cortex (reviewed in Stone et al., 1979). Also, since the proportions of the different ganglion cell types are known to vary across the retina, such a process could serve during normal development to match the numbers of relay cells of different types in different regions of the LGNd with the numbers of ganglion cells of different types in topographically corresponding regions of retina. Such a process could explain why, for example, in the retina as well as the LGNd, the relative proportion of $Y$ cells increases by a factor of about 2.3 between regions representing central and peripheral parts of the visual field (see Leventhal, 1982, for discussion).

\section{Conclusion}

The present study provides evidence that, during the development of cat retina, cell death is capable of "sculpting" the mature patterns of central projections of the different classes of retinal ganglion cells. This cell death is likely to result from classspecific competitive interactions among the axons of retinal ganglion cells. Class-specific cell death may help to mediate the development of the distinctive retinal distributions of the different ganglion cell types as well as the precise, class-specific connections known to exist between retinal ganglion cells and their target neurons in the mature mammalian visual system.

\section{References}

Bunt, S. M., R. D. Lund, and P. W. Land (1983) Prenatal development of the optic projection in albino and hooded rats. Dev. Brain Res. 6: 149-168.

Clark, P. G. H., and W. M. Cowan (1976) The development of the isthmo-optic tract in the chick, with special reference to the occurrence and correction of developmental errors in the location and connections of isthmo-optic neurons. J. Comp. Neurol. 167: 143-164.

Cooper, M. L., and J. D. Pettigrew (1979a) The decussation of the retinothalamic pathway in the cat, with a note on the major meridians of the cat's eye. J. Comp. Neurol. 187: 312-385.

Cooper, M. L., and J. D. Pettigrew (1979b) The retinothalamic pathways in Siamese cats. J. Comp. Neurol. 187: 313-348.

Cowan, W. M., and D. D. M. O'Leary (1984) Cell death and process elimination: The role of regressive phenomena in the development of the vertebrate nervous system. In Medicine, Science and Society: Symposia Celebrating the Harvard Medical School Bicentennial, K. J. Isselbacher, ed., pp. 643-668, Wiley, New York.

Cowan, W. M., J. W. Fawcett, D. D. M. O'Leary, and B. B. Stanfield (1984) Regressive events in neurogenesis. Science 225: 1258-1265.

Fernald, R., and R. Chase (1971) An improved method for plotting retinal landmarks and focusing the eyes. Vision Res. 11: 95-96.

Frost, D. O. (1984) Axonal growth and target selection during development: Retinal projections to the ventrobasal complex and other "nonvisual" structures in neonatal Syrian hamsters. J. Comp. Neurol. 230: 576-592.

Frost, D. O., and G. E. Schneider (1979) Postnatal development of retinal projection in Syrian hamsters: A study using autoradiographic and anterograde degeneration techniques. Neuroscience 4: 1649-1677.

Godement, P., J. Salaun, and M. Imbert (1984) Prenatal and postnatal development of retinogeniculate and retinocollicular projections in the mouse. J. Comp. Neurol. 230: 552-575.
Hamburger, V., and R. W. Oppenheim (1982) Naturally occurring neuronal death in vertebrates. Neurosci. Commun. $1: 39-55$.

Illing, R. B., and H. Wässle (1981) The retinal projection to the thalamus in the cat: A quantitative investigation and a comparison with the retinotectal pathway. J. Comp. Neurol. 202: 265-285.

Insausti, R., C. Blakemore, and W. M. Cowan (1985) Postnatal development of the ipsilateral retinocollicular projection and the effects of unilateral enucleation in the golden hamster. J. Comp. Neurol. 234: 393-409.

Jacobs, D. S., V. H. Perry, and M. J. Hawken (1984) The postnatal reduction of the uncrossed projection from the nasal retina in the cat. J. Neurosci. 4: 2425-2433.

Jeffrey, G., and V. H. Perry (1982) Evidence for ganglion cell death during development of the ipsilateral retinal projection in the rat. Dev. Brain Res. 2: 176-180.

Kelly, J. P., and C. D. Gilbert (1975) The projections of different morphological types of ganglion cells in the cat retina. J. Comp. Neurol. 163: 65-80.

Kirk, D. L., B. G. Cleland, H. Wässle, and W. R. Levick (1976a) Crossed and uncrossed representation of the visual field by brisksustained and brisk-transient cat retinal ganglion cells. Vision Res. 16: $225-231$.

Kirk, D. L., B. G. Cleland, H. Wässle, and W. R. Levick (1976b) The crossed and uncrossed destination of sluggish-concentric and nonconcentric cat retinal ganglion cells, with an overall synthesis of the visual field representation. Vision Res. 16: 233-236.

Kliot, M., and C. J. Shatz (1985) Abnormal development of the retinogeniculate projection in Siamese cats. J. Neurosci. 5: 2641-2653.

Land, P. W., and R. D. Lund (1979) Development of the rat's uncrossed retinotectal pathway and its relationship to plasticity studies. Science 105: 698-700.

Leventhal, A. G. (1982) Morphology and distribution of retinal ganglion cells projecting to different layers of the dorsal lateral geniculate nucleus in normal and Siamese cats. J. Neurosci. 2: 1024-1042.

Leventhal, A. G., J. Keens, and I. Törk (1980) The afferent ganglion cells and cortical projections of the retinal recipient zone (RRZ) of the cat's "pulvinar complex". J. Comp. Neurol. 194: 535-554.

Leventhal, A. G., D. J. Vitek, and D. J. Creel (1985a) Abnormal visual pathways in normally pigmented cats that are heterozygous for albinism. Science 229: 1395-1397.

Leventhal, A. G., R. W. Rodieck, and B. Dreher (1985b) Central projections of cat retinal ganglion cells. J. Comp. Neurol. 237: 216226.

Leventhal, A. G., J. D. Schall, and S. J. Ault (1988) Extrinsic determinants of retinal ganglion cell structure in the cat. J. Neurosci. 8: 2028-2038.

Linden, R., and V. H. Perry (1982) Ganglion cell death within the developing retina: A regulatory role for retina dendrites? Neuroscience 7: 2813-2837.

Mastronarde, D. N., M. A. Thibeault, and M. A. Dubin (1984) Nonuniform postnatal growth of the cat retina. J. Comp. Neurol. 228: $598-608$.

McLoon, S. C., and R. D. Lund (1982) Transient retinofugal pathways in the developing chick. Exp. Brain Res. 456: 277-284.

Murray, M., S. Sharma, and M. Edwards (1982) Target regulation of synaptic number in the compressed retinotectal projection of goldfish. J. Comp. Neurol. 209: 374-385.

$\mathrm{Ng}, \mathrm{A} . \mathrm{Y}$. K., and J. Stone (1982) The optic nerve of the cat: Appearance and loss of axons during normal development. Dev. Brain Res. 5: 263-271.

O'Leary, D. D. M., and W. M. Cowan (1982) Further studies on the development of the isthmo-optic nucleus with special reference to the occurrence and rate of ectopic and ipsilaterally projecting neurons. J. Comp. Neurol. 212: 399-416.

O'Leary, D. D. M., C. R. Gerfen, and W. M. Cowan (1983) The development and restriction of the ipsilateral retinofugal projection in the chick. Dev. Brain Res. 10: 93-109.

O'Leary, D. D. M., J. W. Fawectt, and W. M. Cowan (1986) Topographic targeting errors in the retinocollicular projection and their elimination by selective ganglion cell death. J. Neurosci. $6: 3692-$ 3705 .

Oppenheim, R. W. (1981) Neuronal cell death and some related regressive phenomena during neurogenesis: A selective historical review and progress report. In Studies in Developmental Neurobiology: Essays in Honor of Viktor Hamburger, W. M. Cowan, ed., pp. 74-133, Oxford U. P., New York. 
Perry, V. H., and R. Linden (1982) Evidence for dendritic competition in the developing retina. Nature 297: 683-685.

Perry, V. H., R. Oehler, and A. Cowey (1984) Retinal ganglion cells that project to the dorsal lateral geniculate nucleus in the macaque monkey. Neuroscience 12: 1101-1123.

Rapaport, D. H., and J. Stone (1983) Time course of morphological differentiation of cat retinal ganglion cells: Influences on soma size. J. Comp. Neurol. 221: 42-52.

Rowe, M. H., and B. Dreher (1982) Retinal W-cell projections to the medial interlaminar nucleus in the cat: Implications for ganglion cell classification. J. Comp. Neurol. 204: 117-133.

Schall, J. D., S. J. Ault, D. J. Vitek, and A. G. Leventhal. (1988) Experimental induction of an abnormal ipsilateral visual field representation in the geniculocortical pathway of normally pigmented cats. J. Neurosci. 8: 2039-2048.

Schneider, G. E., S. Jhaveri, M. A. Edwards, and K. So (1985) Regeneration, re-routing, and redistribution of axons after early lesions: Changes with age, and functional impact. Recent Achievements in Restorative Neurology 1: Upper Motor Neuron Functions and Dysfunctions, pp. 291-310, Karger, Basel.

Sretavan, D. W., and C. J. Shatz (1986) Prenatal development of retinal ganglion cell axons: Segregation into eye specific layers within the cat's lateral geniculate nucleus. J. Neurosci. 6: 234-251.

Stone, J. (1966) The nasotemporal division of the cat's retina. J. Comp. Neurol. 126: 585-600.

Stone, J., and E. Johnston (1981) The topography of primate retina: A study of the human, bushbaby, and new- and old-world monkeys. J. Comp. Neurol. 196: 205-223.

Stone, J., J. Leicester, and S. M. Sherman (1973) The nasotemporal division of the monkey retina. J. Comp. Neurol. 150: 333-348.
Stone, J., J. E. Campion, and J. Leicester (1978) The nasotemporal division of the retina in the Siamese cat. J. Comp. Neurol. 180:783798.

Stone, J., B. Dreher, and A. G. Leventhal (1979) Hierarchical and parallel mechanisms in the organization of the visual cortex. Brain Res. Rev. 1: 345-394.

Stone, J., A. G. Leventhal, C. R. R. Watson, J. Keens, and R. Clarke (1980) Gradients between nasal and temporal areas of the cat retina in the properties of retinal ganglion cells. J. Comp. Neurol. 192:219235.

Stone, J., D. H. Rapaport, R. W. Williams, and L. Chalupa (1982) Uniformity of cell distribution in the ganglion cell layer of prenatal cat retina: Implications for mechanisms of retinal development. Dev. Brain Res. 2: 231-242.

Sur, M., R. E. Weller, and S. M. Sherman (1984) Development of Xand $Y$-cell retinogeniculate terminations in kittens. Nature $310: 246-$ 249.

Thanos, S., and F. Bonhoeffer (1984) Development of the transient ipsilateral retinotectal projection in the chick embryo: A numerical fluorescence-microscopic analysis. J. Comp. Neurol. 224: 407-414.

Vitek, D. J., J. D. Schall, and A. G. Leventhal (1985) Retinal ganglion cell classes in the pigmented ferret: Morphology and central projections. J. Comp. Neurol. 241:1-11.

Wässle, H., and R. B. Illing (1980) The retinal projection to the superior colliculus in the cat: A quantitative study with HRP. J. Comp. Neurol. 190: 333-356.

Williams, R. W., M. J. Bastiani, B. Lia, and L. M. Chalupa (1985) Growth cones, dying axons and developmental fluctuations in the fiber population of the cat's optic nerve. J. Comp. Neurol. 246: 3269. 